\title{
SYPHILITIC AORTITIS: ITS DIAGNOSIS AND TREATMENT *
}

\author{
WARFIELD T. LONGCOPE, M.D. \\ NEW YORK
}

For some years I have been much interested in the condition which is now generally known as syphilitic aortitis or mesaortitis. At first my observations were particularly directed to the pathological lesion itself; later the exact etiology of these changes became the subject for study, while at present it is the diagnosis and treatment of the disease to which most time is devoted. Up to the present I have had an opportunity at the Pennsylvania ${ }^{1}$ and University hospitals in Philadelphia, and at the Presbyterian Hospital in New York of studying sixty-three cases in which syphilitic aortitis was proved to exist at autopsy, or in which the diagnosis seemed reasonably sure from the combination of certain symptoms and signs, with a positive Wassermann reaction during life. Of the entire number, twenty have been treated with salvarsan. But except for the fact that the diagnosis and treatment of this disease are of such importance, and that the observations have perhaps suggested certain lines for further study, it would scarcely be justifiable to offer such a familiar subject for serious consideration.

Since the time of Morgagni, syphilis has been recognized as a factor in the etiology of aneurysm, as well as of other less well defined cardiorascular diseases, but it was not until the publication of the anatomical studies of Döhle, ${ }^{2}$ in 1888, followed by the work of Heller and his pupils on syphilitic aortitis that the direct relationship between the two was made apparent. Döhle's excellent description and illustrations of the pathology of syphilitic aortitis really leaves little to be added on that score, while the accounts of the French, and particularly Huchard, ${ }^{3}$ Dieulafoy, ${ }^{4}$ Gallavardin ${ }^{5}$ and Fournier ${ }^{6}$ of the symptomatology and diagnosis of "Aortite sub-aigué," a subject to which they have devoted much attention, and to which Germans and Anglo-Saxons until recently have paid comparatively little heed in spite of the original account by Cor-

*Submitted for publication in the ARchives Oct. 21, 1912.

1. For an opportunity of studying the cases at the Pennsylvania Hospital I am indebted to Drs. Morris J. Lewis, J. C. Wilson, James Tyson, J. Norman Henry, Alfred Stengel, and the late Dr. Arthur V. Meigs.

2. Döhle: Deutsch. Arch. f. klin. Med., 1895, lv, 190.

3. Huchard: Traité clinique des maladies du coeur et de l'aorte, Paris, 1899.

4. Dieulafoy: Clinique medical de l'Hôtel Dieu, Paris, 1896-7, p. 71 .

5. Gallavardin: Precis de maladies du coeur et d l'aorte, Paris, 1908.

6. Fournier: Traite de la syphilis, 1899. 
rigan, ${ }^{\top}$ and the articles of Allbutt, ${ }^{\mathrm{s}}$ cover this aspect of the disease in a fajrly thorough manner. The more recent lectures of Mitchell Bruce, ${ }^{9}$ Schwar», ${ }^{10}$ Breitmann ${ }^{11}$ and Goldscheider ${ }^{12}$ also contain good clinical descriptions.

The important conclusion of Döhle that syphilis produced a characteristic type of aortitis bronght forth some adverse criticism, but no very wide-spread interest, and it was not until the subject was presented before the Deutsche Pathologische Gesellschaft in 1903 by Chiari, ${ }^{13}$ Benda $^{14}$ and Narchand ${ }^{15}$ that arteritis became a common subject for study. During the following years many papers appeared giving anatomical descriptions and statistical records, but as this literature is thoroughly reviewed in Fahr's ${ }^{1 \mathrm{i}}$ paper, and in Herxheimer's ${ }^{17}$ excellent article, it is unnecessary to do more than refer to these publications. Indeed, the morbid anatomy of the process has been made so familiar through numerous original contributions, as well as by descriptions and pictures in recent text-books such as those of Adami and Aschoff, that it seems scarcely necessary to gire more than the briefest outline of the anatomical changes as I have observed them.

\section{ANATOMICAL CHANGES}

The gross appearances of syphilitic aortitis are in themselves fairly characteristic. The root of the arta and the arch are most commonly affected, but the jrocess naty be found anywhere throughout the length of the vessel. In several instances I have seen an extensive, though circumscribed process in the abdominal aortat. The lesion as a rule is quite sharply confined to a certain area. The smallest areas and probably the earliest which we can recognize consist of well outlined, pale grey, rather translucent, elevated, succulent looking patehes 0.5 to 2 or $3 \mathrm{~cm}$. in diameter. On seetion the elevated portion of the vessel is translucent and grey; beneath this and corresponding to the media one sees opaque, vellow streaks and patches running the length of the section, and sometimes 1 to $2 \mathrm{~mm}$. in thickness. These occasionally sink beneath the level of the knife cut. The larger and more advanced areas form isolated or conglomerate patches 4 to $10 \mathrm{~cm}$. in diameter, or completely surround the circumference of the vessels. The distal margin is usually very sharply defined, and beyond this line of demarcation, which may be found somewhere along the arch, the smooth, delicate aorta stretches in wonderfully sharp contrast to the diseased portion. The surface of the larger areas is extremely irregular. The elevated patches mentioned above alternate, or are irregularly intermingled with yellowish, scarred, pitted and seared areas, or with greyish patches that look like thin, crinkled silk. When the process is

7. ('errigan: Edinburgh Med. Jour., 1832, xxxvii, No. 111, 225.

8. Allbutt: Allbutt's Syst. Med.

ก. Bruce, Mitchell: Lancet, London, 1911, ii, 69, 141, 205.

10. Schwarz: Centralbl. f. die ges. Therap., 1911, xxix, 225.

11. Breitmann: Berl. klin. Wehnsehr., 1911, xlviii, 1763.

12. Goldscheider: Med. Klin., 1912, viii, 471.

13. Chiari: Verhandl. d. Deutseh. path. Gesellsch., 1903, p. 137.

14. Benda: Verhandl. d. Deutsch. path. Gesellsch., 1903, p. 164.

15. Marchand: Verhandl. d. Deutsch. path. Gesellsch., 1903, p. 197.

16. Fahr: Virchows Arch. f. path. Anat., 1904, clxxvii, 508.

17. Herxheimer: Lubarch Ostertag Ergelon. d. allg. Path. u. Path. Anat., 1907, $x i, 195$. 
extensive the wall at points is thinned, or there may be tiny aneurysmal bulgings no bigger than a pea. When the process is widespread, and apparently of long standing, there is an irregular, or diffuse dilatation of the vessel. True saccular aneurysms are common. Not infrequently the changes are marked about the mothis of the branches of the arch. Oecasionally this causes distinet narrowing of the innominate or left carotid. Except in the very oldest cases one never sees atheromatous patches containing cholesterin erystals or ealeification. When these changes occur they are associated with a typical endarteritis deformans ruming thronghout the length of the aorta. When the process advances to the aortic ring, as it often does, the mouths of the coronary arteries may be partly occluded, or even reduced to a pin-hole point, though the lesion rarely extends far into the coronary arteries themselves. With the involvement of the sinuses of Valsalva, and the aortic ring, there may be pouching of one and distention of the other, so that the circumference of the ring, instead of being 5 to $7 \mathrm{~cm}$. may reach 9 to $11 \mathrm{~cm}$. The aortic flaps likewise become involved, and show a curious thickcned and wrinkled appearance, which causes more or less retraction and incompetence. though in certain cases of typical aortic insufficiency, the valves are surprisingly large and pliable, while the aortic ring is widely dilated. To this Corrigan limself called attention. Even below the flaps on the endocardium in some instances there are crescentic lines of greyish thickening.

Microscopically the carliest lesions which may be definitely recognized show that all three of the main coats of the aorta are involved. The adventitia shows small accumulations of small round cells about the vasa vasorum, and the intima of both arteries and veins may be thickened. Minute blood-vessels extend into the media, and are surrounded along their courses by accumulations of plasma cells, small round cells and epithelioid cells. Slight breaks in the elastic tissue are observed in Weigert's stain. The cells of the intima are proliferated and heaped up to form a projection from the inner surface of the vessel.

In the more extensive lesions the perivascular infiltration of the adventitia is very pronounced. The media presents very characteristic areas of coagulation neerosis surrounded and partly infiltrated with plasma cells and small round cells. Giant cells may be encountered. They sometimes contain fragments of elastic tissue. The elastic tissue in special stains is seen to be destroyed, torn and fragmented, and is usually entirely absent in the center of such a patch. The cellular proliferation of the intima is marked. These areas of necrosis, or miliary gummata, may be of considerable size, and in two specimens which I have studied they involved not only the media, but large areas in the adventitia, and even the adjacent heart wall, formiug true gummata, whish were readily visible macroscopically. There is frequently a sacculated dilatation of the arterial wall which may vary from a depression scarcely perceptible to a well-formed aneurym of small si\%e.

The third characteristic picture appears to represent a later stage of the process, and shows a scarred, distorted vessel wall, almost unrecognizable as such, with perlaps complete destruction of all three coats of the artery. Small foci of necrosis surrounded by connective tissue, partly vascularized and infiltrated with varying numbers of plasma cells and small round cells take the place of the media, and extend in marked instances both to adventitia and media, while in appropriate stains the curled fragments of elastic tissue may be seen here and there throughout the lesion.

In ecrtain cases we have found but one of these three types or stages of the process, but as a rule two or all of them are seen in different portions of the vessel walls.

Extending from the root of the aorta the process frequently involves the valves of the aortic orifice and the aortic ring itself. The changes in the valves in such cases consist in localized and diffuse infiltrations of small round cells and plasma cells. 


\section{RELATION OF SYPHILIS TO AORTITIS}

That such lesions are in themselves characteristic, and may readily be recognized, is granted by most observers, but that they are always and exclusively due to syphilis is questioned still by many. Evidence is accumulating, however, to show that syphilis is certainly the commonest, if not the exclusive cause. The statistical studies of Marchand, Benda, Herxheimer and Fahr, have been mentioned, and the subject has been collectively reviewed recently by Eich. ${ }^{\circledR 8}$ There is general agreement as to the frequency of a history, or other evidence of syphilis in cases showing this type of aortitis.

More direct evidence was brought forward by Reuter ${ }^{19}$ in 1906, who described spirochetes in the walls of an aorta affected by this gummatous process. His observation has been confirmed by Schmorl, ${ }^{20}$ Benda $^{21}$ and by Wright, ${ }^{2}$ who was able to demonstrate spirochetes, often in enormous numbers, in all of five cases of mesaortitis. From the results of some studies which $\Upsilon$ have made, and which Dr. Jean V. Cooke undertook at the Pennsylvania Hospital, the presence of spirochetes in these lesions, as might be expected, cannot by any means be constantly demonstrated with Levaditi stains. Portions of the aorta from seven cases of typical syphilitic aortitis, all of which during life had given a positive Wassermann reaction, were stained by the Levaditi method and searched carefully. In three of these, spiral organisms were found in moderate numbers, sparsely scattered through the thickened intima and underlying portions of the diseased vessel wall. That these organisms are Treponema pallidum seems almost certain, though actual proof of such by culture from the arterial lesions, a most difficult task, or direct inoculation into animals, has not as yet been accomplished.

Vanzetti, ${ }^{23}$ on the other hand, has claimed to produce an arterial lesion in rabbits which simulated syphilitic aortitis in man by the inoculation of bits of syphilitic rabbits' testicles into the sheath of the carotid artery. In from twenty to forty-one days the syphiloma develops about the wall of the vessels. Spirochetes are found only in the adventitia at the seat of inoculation. Though his pictures and descriptions do not convince one that the experimental lesion corresponds precisely with the aortic lesion in man, yet his observation that the first alteration in the vessel wall after perivascular inoculation is a proliferation of intima cells, is of much interest in connection with the histogenesis of the disease in

18. Eich: Frankfurter Ztschr. f. Pathol., 1911, vii, 373.

19. Reuter: München. med. Wchnschr., 1906, liii, 10, 77s; Ztschr. f. Hyg. и. Infektionskr., 1906, liv, 49.

20. Schmorl: München. med. Wchnschr., 1907, liv, 188.

21. Benda: Berl. klin. Wchnschr., 1906, xliii, 989.

22. Wright: Boston Med. and Surg. Jour., 1909, clx, 539.

23. Vanzetti: Tr. First Internat. Cong. Path., Torino, October, 1911, p. 171. 
the human artery, where the lesions in the media are usually attended by a proliferation of the cells of the intima.

It remains to be seen, however, whether any other infectious agent may produce the same lesion. Klotz ${ }^{24}$ has described alterations in the aorta in cases of rheumatic fever in children which bear some likeness to those ascribed to syphilis. In any such studies it is of the utmost importance to exclude the possibility of congenital syphilis, for, as Klotz ${ }^{24}$ himself has shown, lesions practically the same as syphilitic aortitis in the acquired disease may be found in infants the subject of congenital syphilis. Wiesner ${ }^{25}$ and Rach and Wiesner ${ }^{26}$ have paid considerable attention to this subject, and have found changes in 59 per cent. of the syphilitic fetuses examined. These observations have been confirmed by Bruhns ${ }^{27}$ and recently by Rebaudi, ${ }^{28}$ who, in five cases, was able to demonstrate spirochetes scattered through the aortic lesion. Rach and Wiesner state that spirochetes were not once found in any of seven cases. These obscrvations afford, besides, strong support to the idea that the disease in adults is due to syphilis.

To the above evidence of the syphilitic nature of this process must be added the valuable results obtained from the use of the Wassermann reaction. Eich, who perhaps has had the largest series of cases controlled by autopsies, obtained a positive Wassermann reaction in 81.8 per cent. of forty-four cases that showed characteristic syphilitic aortitis at autopsy. His technic may be criticised, however, since in a number of instances he employed post-mortem blood. Pearce ${ }^{29}$ collected seventy cases of mesaortitis from the literature, in 78.5 per cent. of which the Wassermann reaction was positive.

A question of extreme importance is to determine the time at which the aorta becomes infected. It is known that syphilis during the late primary stage becomes a general septicemia, and in certain cases during this period it is possible to demonstrate spirochetes in the circulating blood (Fruhwald, ${ }^{30}$ Uhlenhuth and Mulzer ${ }^{31}$ ). Following this general invasion of the body the spirochetes lodge in different organs and tissues, spreading by way of the lymphatics; and it is highly probable that the infection of such organs as the aorta, the nervous system and the liver takes place at this period. For some reason, as yet unexplained, the root of the aorta and ascending arch seem to be one of the sites of predilection for the organism. Whether or not there are changes in or about the aorta

24. Klotz: Jour. Pathol. and Bacteriol., 1907, xii, 11.

25. Wiesner: Centralbl. f. Path. u. path. Anat., 1905, xvi, 822.

26. Rach and Wiesner: Wien. klin. Wehnschr., 1907, xx, 521.

27. Frulıns: Deutsch. med. Wehnschr., 1906, No. 19.

28. Rebaudi: Monatschr. f. Geburtsh. u. Gynäk., 1912, xxxv, 681.

29. Pearce: Tinf Archives Ixt. Mlf., 1910, vi, 478.

30. Fruhwald: Wien. klin. Wehnschr., 1912, xxv, 584.

31. Uhlenhuth and Mulzer: Berl. klin. Wchnschr., 1912, xlix, 152. 
during the secondary stage is a question which at present must be left undecided, but it is quite certain that the results of the invasion of the aorta may become manifest soon after the primary infection. Indeed, in the secondary stage of syphilis there may be certain symptoms and signs referable to the cardiovascular system. Fournier mentions palpitation, arhythmia and tachycardia, but as they occur chiefly in women he ascribes them to functional disorders of the nervous system. Grassmann, ${ }^{32}$ in his study of the cardiovascular system of 288 cases of secondary syphilis, states that in 85 per cent. there were disturbances in the rate or rhythm of the pulse, while in 40 per cent. accidental cardiac murmurs usually with dilatation of the heart occurred. Though syphilitic aortitis with its complications-aortic insufficiency, aneurysm, dilatation of the arch and angina pectoris-are usually referred to as late or even parasyphilitic and metasyphilitic affections, there are instances on record in which these conditions have appeared shortly after infection. Harlow Brooks $\mathrm{s}^{33}$ mentions one case in which the perforation of an aneurysm took place before the secondary rash had fully appeared, and another in which a serious aortic lesion, sufficient to cause death, developed within six months of infection. Liek, ${ }^{34}$ too, describes a most interesting example in a young man 26 years of age, who developed within seven months after contracting a chancre, dilatation of the aorta visible by $x$-ray. There were mild anginoid symptoms. Two of my patients died from the effects of syphilitic aortitis four years after the development of a chancre, and such instances are not excessively rare. It seems possible, therefore, that even when the effects of the infection do not make themslves apparent for many years, the actual invasion of the aorta may take place during the secondary stage.

\section{CHIEF SIGNS AND SYMPTOMS}

Early in the disease, no doubt, the involvement of a small portion of the aorta may be of slight immediate significance, but with the extension of the process, there result four grave conditions-diffuse dilatation of the arch, aneurysm, aortic insufficiency and angina pectoris. I have been particularly interested in the association of aortic insufficiency with syphilitic aortitis. In a study of 76 cases of chronic endocarditis that came to autopsy at the Pennsylvania Hospital, 43 cases gave symptoms and signs during life of aortic insufficiency. In about half, or 21 of these, the mitral valve as well as the aortic valve was diseased, and showed retraction or stenosis, while the individuals were principally children with a history of rheumatic fever. In none of these was syphilitic aortitis

32. Grassmann: Deutsch. Arch. f. klin. Med., 1900, lxviii, 455; 1901, Ixvix, 58 and 264.

33. Brooks, Harlow: Med. Rec., New York, 1912, lxxxi, 351.

34. Liek: Fortschr. a. d. Geb. d. Röntgenstrahle, 1911, xvii, 23.

35. Longcope: Jour. Am. Med. Assn., 1910, liv, 118. 
present. In the remaining 22 cases, all of which showed involvement of the aortic valves alone, 18 , or 81.5 per cent., were associated with syphilitic aortitis.

With the advent of the Wassermann reaction a valuable method was obtained for the study of these cases of cardiovascular disease, and the astonishing frequency with which syphilis appeared as an etiological factor soon became apparent. Citron, ${ }^{36}$ in 1908, first reported that of 16 cases of aortic insufficiency, 62.6 per cent. gave a positive Wassermann reaction. In the next year or so came the reports of Danielopolu, ${ }^{37}$ Schutze, ${ }^{38}$ Collins and Sachs, ${ }^{39}$ Clough, ${ }^{40}$ Laubry and Parvu, ${ }^{41}$ Deneke, ${ }^{42}$ Donath, ${ }^{43}$ Oigaard, ${ }^{44}$ Bruchner and Galesco ${ }^{45}$ and Krefting, ${ }^{46}$ giving in all, 182 cases of aortic insufficiency, in 135 of which, or in 74.1 per cent., the Wassermann reaction was positive. Pearce, in 1910, collected the statistics of $5 \%$ cases of aneurysm, 38 of which gave positive reactions, 70 cases of mesaortitis, $5 \%$ of which gave positive reactions, and 214 cases of general arterial sclerosis, 29 of which gave positive reactions. During the years 1909 and $1910, I^{17}$ made Wassermann tests, using the original Wassermann technic, on 12 cases of aneurysm, 11 of which gave positive reactions, and on 47 cases of aortic insufficiency, 35 of which, or 74.4 per cent., gave positive reactions. Of the positive cases, 7 came to autopsy, and all showed typical mesaortitis with involvement of the aortic ring, or of the wall above. In the wall of the aorta of three patients spirochetes were found. The 10 cases of aortic insufficiency which gave negative reactions were, save one, combined with disease of the mitral valve. An autopsy in this one case of pure aortic insufficiency giving a negative Wassermann reaction showed no evidence of syphilitic aortitis. Autopsy on the one case of aneurysm which gave a negative Wassermann reaction showed a definite but old scarred syphilitic aortitis.

Two of the cases of aortic insufficiency, which gare positive Wassermann reactions, were associated with mitral stenosis. One of these came to autopsy, and showed typical syphilitic aortitis involving the aortic leaflets. Spirochetes were present in fair numbers in the wall of the aorta. There was marked irregular thickening and fusing of the mitral leaflets. A nodular, fibrous mass was found on the posterior leaflet. The

36. Citron: Berl. klin. Wehnschr., 1908, xi, 2142.

37. Danielopolu: Compt. rend. Soc. de biol., 1908, lxiv, 971.

38. Schutze: Deutsch. Ztschr. f. Chir., 1908, xer, 13.

39. Collins and Sachs: Am. Jour. Med. Se., 1909, cxxxviii, 344.

40. Clough: Bull. Johns Hopkins Hosp., 1910, xxi, 70.

41. Laubry and Parvu: Compt. rend. Soc. de biol., 1909, lxvi, 750, lxvii, 48.

42. Dencke: Deutsch. med. Wchnschr., 1909, xxxv, 2148.

43. Donath: Berl. klin. Welmschr., 1909, xlvi, 2015.

44. Oigaard: Arch. de mal. de coeur., 1910, iii, 478.

45. Bruchner and Galesco: Compt. rent. Soc. de biol., 1910, lxviii, 74.

46. Krefting: Deutsch. Med. Wehnschr., 1910, xxxvi, 93.

47. Longeope: Bull. Aver Clin. Lab., 1910, No. 6, p. 60. 
chorda tendineae were thick and looked as though scarred. Spirochetes could not be found in the mitral lesion. Whether the mitral stenosis was a result of the syphilitic process, or caused by some acute infection, such as rheumatic fever, of which there was no history, could not be determined, but it is evident that mitral stenosis may exist with syphilitic aortitis.

To control the above observations Wassermann reactions were performed on fifty cases, including various types of mitral disease, cardiac hypertrophy secondary to nephritis, and general arterial sclerosis. In the entire series only three positive Wassermann reactions were encountered, two in cases of chronic nephritis with arteriosclerosis, and one in a case of mitral stenosis and insufficiency. This proportion is at least what one might expect in any material collected among adults in a large general hospital.

Since the completion of these studies still other confirmatory reports have been made by Grau, ${ }^{48}$ Orkin, ${ }^{49}$ Ledermann, ${ }^{50}$ Bie,,${ }^{51}$ Fiessinger, ${ }^{52}$ Jacobeus, ${ }^{53}$ Comesatti, ${ }^{54}$ Hirtz and Braun, ${ }^{55}$ Weintraud, ${ }^{56}$ Cummer and Dexter, ${ }^{\circ 7}$ Goldscheider ${ }^{\circ 8}$ and others. The percentage of positive Wassermann reactions are variously given: for general cardiovascular diseases from 25 per cent. to 68 per cent.; for aortic insufficiency from 75 per cent. to 100 per cent.; for aneurysm from 85 to 95 per cent., and for aortic diseases in general, including aneurysm, diffuse dilatation and angina pectoris, from $7 \tilde{5}$ to 88 per cent.

Wolfsohn ${ }^{59}$ has recently found that positive reactions to Noguchi's luetin in cardiac disease are even more frequent than the Wassermann reaction. In 12 cases, including 6 of aortic insufficiency, 4 of aneurysm, and 2 of myocarditis, 11, or 91 per cent., reacted to luetin. The one negative reaction occurred in a case of myocarditis. The Wassermann reaction was positive in but 58.3 per cent.

Even from these rather small statistics, confirming as they do the anatomical studies, it may be seen how extremely common syphilitic aortitis and its complications are, and what a large proportion of serious diseases of the cardiovascular system in adults may be dependent on this

48. Grau: Ztschr. f. klin. Med., 1911, lxxii, 292.

49. Orkin: Berl. klin. Wehmsehr., 1912, xlix, 1177.

50. Iedermann: Deutsch. Med. Wehnschr., 1912, xxxviii, 1038.

51. Pie: Ugesk. f. Laeger, 1911, Ixxiii, No. 11 ; Abstr. in Jour. Am. Med. Assn., 1911 , Ivi, 1158 .

52. Fiessinger: Bull. de l'Acad. de méd., 1911, series 3, lxvi, 135.

53. Jacobeus: Deutsch. Arch. f. klin. Med., 1911, cii, 44.

54. Comesatti: Riv. crit. di clin. med., 1911, xii, 561 and 581.

55. Hirtz and Braun: Bull. et mém. Soc. d. hôp., 1911, series 3, xxxi. 363.

56. Weintraud: Therap. d. Gegenw., 1911, lii, 442.

57. Cummer and Dexter: Jour. Am. Med. Assn., 1912, lix, 419.

58. Goldscheider: Med. Klin., 1912, viii, 471.

59. Wolfsohn: Bull. Johns Hopkins ITosp., 1912, xxiii, 223. 
disease. It is evident that most aneurysms of the arch of the aorta, the majority of cases of aortic insufficiency in adults, uncomplicated by mitral disease, many cases of angina pectoris, particularly in individuals under 50 years of age, and a large proportion of cases of dilatation of the aorta are only incidents in the development and progress of syphilitic aortitis, and unfortunately in many instances are the first signs that attract our attention to the disease. But it is most important that we should not lose sight of the main and underlying process, and serious as the complications are, our attention should be directed to a study of the discased aorta rather than to the late manifestations.

\section{CLINICAL PICTURE}

The clinical picture, it is true, is made up principally of the symptoms and signs which accompany these end results, but there are certain features common to all types of the disease the explanation for which is somewhat difficult to give, but which may repay further study. To many clinicians the disease has been familiar for years. Aside from the wellknown descriptions given by Hurhard, Dieulafoy, Gallavardin, Fournier and Allbuttf, the symptomatology and diagnosis have recently been discussed by Mitchell Bruce and Osler ${ }^{60}$ in their Lumleian Lectures, and by Breitmann, Schwarz, Goldscheider, Bruhns, ${ }^{61}$ Oigaard, ${ }^{62}$ Grau, Fiessinger, Orkin and Cummers and Dexter.

The 63 cases on which this study is based, include 43 cases of aortic insufficiency, 4 of which were combined with aneurysm, 8 cases of aneurysm alone, and 12 cases of aortitis associated with dilatation of the arch, myocarditis, angina pectoris, or a combination of these conditions. The diagnosis was made or confirmed at autopsy in 29 cases; in 10 of these the Wassermann reaction was performed during life and found positive. In the remaining 34 cases the Wassermann was positive. For the Wassermann reactions in 13 cases which were studied at the Presbyterian Hospital, I am indebted to Dr. Albert Lamb. In making these tests the Noguchi modification was used. In all the other cases I employed the original Wassermann technic.

\section{AGE INCIDENCE}

Most authors have mentioned the fact that these cardiovascular changes due to syphilis are met with in comparatively young people. In Bie's statistics the average age at which the symptoms of syphilitic aortitis developed was 42 ; for aneurysm 50 , and for myocardial disease 52. Mitchell Bruce, in a study of 70 odd cases gives the average age at

广Allbutt: Lancet, 1903, ii, 139; Brit. Med. Jour., 1906, i, 5.

60. Osler: Lancet, London, March 12 and 26 and April 9, 1910.

61. Bruhns: Berl. klin. Wehnschr., 1906, xliii, 513.

62. Oigaard: Ztschr. f. klin. Med., 1911, lxxiii, 440. 
which the first manifestations occurred as 49. Of Cummers and Dexter"s 27 patients, 85 per cent. were between the ages of 35 and 55 years. In my own series, the majority of the patients were young, as may be seen in the following table:

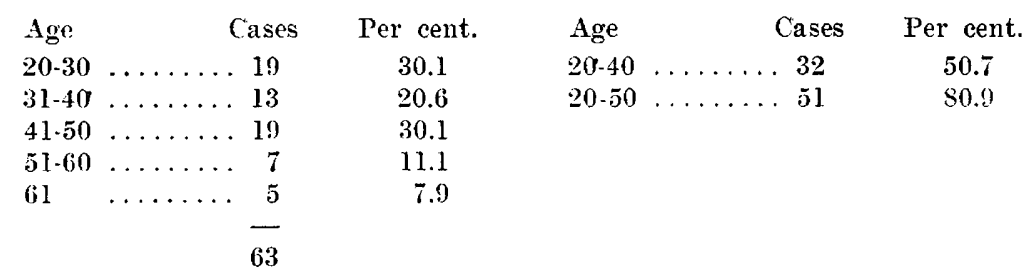

Orer one-half of these patients were less than to years of age, and 80.9 per cent. under 50. Almost a third of the patients were under 30 years of age. The youngest patient was a colored woman of $22 . \quad$ At autopsy there was extensive syphilitic aortitis. There were three other patients under 25, all of which eame to autopsy and showed extensive syphilitic aortitis. The oldest patient was 68 . As a rule, the aneurysms occurred in the older subjects. Except for one case in which a small aneurysm was found at autopsy in a woman of 26 , most of the individnals, 10 out of 13 , were over 40 , and 6 were over 50 .

Of the 63 eases, 51 were men; 25 , or about half, were negroes. Of the 12 women, 10 were negroes.

It has been generally assumed that the symptoms of syphilitic aortitis develop as a late event in the disease. In Bruce's statistics the average latent period between the time of infection and the onset of symptoms was 25 years, in Cummer and Dexter's report $1 \% .2$ years. Bruce gives the minimum period as 5 years, the maximum as 54 . Bie points out that symptoms in these cases make their appearance about 15 years later than they do in rheumatic ferer. Owing to the difficulty in obtaining an accurate history I eonld determine such data in but 2:3 cases. Roughly, the average latent period was 16.4 years, very nearly that given by Cummer and Dexter. The shortest period was 3 years, and there were 4 other cases under 5 years. 'The longest latent period was 35 years. Bearing on this question of latency is an interesting report by Biermann. ${ }^{63}$ Reference has already been made to the changes found in the aorta of congenital syphilitics, and Biermann has recently described a case of congenital syphilis in a girl of 19, who showed dilatation of the aorta with fever. He considers this as an instance of congenital syphilitic aortitis. Wentworth, ${ }^{64}$ too, has recently reported a series of Wassermann tests in children among which were five cases of congenital heart disease, two of which gave positive reactions. It is evident that there may be

63. TBiermann: Deutsel. med. Wehnschr. 1911, xxxvii, $115 \%$.

64. Wentworth: Am. Jour. Dis. Child., 1912, iii, 363. 
syphilitic disease of the aorta which remains latent and gives no simptoms over long periods of time.

It is impossible to determine whether any secondary factors acted as predisposing causes in the development of the aortitis. Many of the men were hard working. A history of alcohol, or abuse of tobacco, was not particularly striking. One patient had tabes dorsalis. The frequent association of tabes and aortic disease is well known, and the question las been thoroughly discussed by Heitz."."

\section{SYMPTOMS}

The symptoms which have attracted the attention of every one who has written on the subject are pain, dyspnea, often on slight exertion, palpitation and tachycardia. Pain was a prominent symptom in 60 per cent. of Bruce's cases. In one-half it was precordial, in the other half anginal in character. Dyspnea occurred in 60 per cent., palpitation in $6 \% .5$ per cent. In my series pain of one sort or another, excluding the continuous cervicobrachial neuralgic pains of ancurysm, occurred in 42 cases, or 66.6 per cent.; dyspnea in 49 , or 77.7 per cent. Palpitation and tachycardia were less frequent.

Pain is an interesting symptom not only because it is so characteristic of this type of cardijorascular disease, but on account of its relationship to the state of angina pectoris, the true nature of which is still so imperfectly understood. It is frequently the first symptom (29 cases), and alone or in combiation with ryspnea of various types may be the only symptom for long periods (9 cases). Osler ${ }^{66}$ has called attention to the anginoid pain which may precede the appearance of an aneurysm. The cervicobrachial neuralgia, so common in aneurysm, I have not included in this description. The pain is of various kinds. In the majority of cases the patient complains either of a constant or intermittent dull pain beneath the stermum. Sometimes it is described as a painful constriction or oppression, sometimes as a "gripping sensation that comes up from the stomach, and catches at the heart or throat." Mild at first, these disagreeable sensations usually increase in severity, and intermittent attacks become more frequent. In a majority of cases the pains are made worse by exercise. Beginning with mild attacks the patient may one day have a typical paroxysm of angina pectoris accompanied by fear of impending death, and with radiation of pain to the neck, left shoulder, or down the left arm. Rarely the disease starts with severe, typical angina pectoris. Characteristic attacks of angina pectoris occurred in eight of my patients, five of whom had aortic insufficiency. Two patients dropped dead.

65. Ileit\%: Les nerf; du coeur chez les tabétiques, Paris, 1903.

66. Osler: Med. Chron., May, 1906. 
Although the attacks of angina may be free from any disturbances in respiration, very frequently they are closely associated with distinct changes. Occasionally the patient stops breathing in full inspiration; more often there is dyspnea of moderate grade, or attacks of paroxysmal dyspnea, to be described later, accompany the pain so that it is sometimes difficult to distinguish the two. Dyspnea is frequently associated with the milder substernal pain. In the attacks of angina which are free from dyspnea there may be a sharp rise in blood-pressure; in one case from 110 systolic to 170 systolic.

The dyspnea itself is a symptom of the greatest interest, and in one of its forms seems to be highly characteristic of the disease. In the majority of cases there is early dyspnea on slight exertion. In thirty-one cases, or about half, it was one of the first, if not the first symptom. In some cases this slight shortness of breath gradually becomes worse, especially when aortic insufficiency supervenes, until the patient finally shows the constant respiratory difficulty common in broken cardiac compensation. In a second group of cases the dyspnea assumes another and more interesting, though most distressing form. In this group it is paroxysmal in nature, coming on in attacks of five to fifteen minutes' duration. Such attacks were present in nine of my patients, all of whom had aortic regurgitation. These paroxysms may be absolutely the first symptom (seven cases). They vary greatly in number, from two to three during the entire course of the disease, to four or five a day over periods of months. In two cases they occurred daily for almost a year. Though this phenomenon is most common when aortic insufficiency is present, it is seen in cases in which signs of cardiac decompensation do not develop for months, and in one case which is now under observation there have never been signs of decompensation, unless, indeed, these attacks are considered as such. Sometimes the attack is brought on only by exertion, but in the majority of cases the paroxysm is absolutely independent of exercise, and not infrequently strikes the patient like a thunderbolt, often while he is asleep at night. Between attacks he is usually able to perform his daily duties. I have observed a number of such attacks in different individuals, and the following notes made at the bedside will give some idea of their nature.

"Suddenly during roumds at 10:40 a. $m$. the patient showed signs of great distress. He sat up in bed, and gave a sharp agonized cry for help. Going immediately to the bedside he was found sitting up, leaning forward with a pained, anxious expression, and showing the most marked dyspnea. He implored us to relieve him of his distress, but talked quite intelligently throughout the attack, and said there was no actual pain, but terrific difficulty in getting his breath. The supraclavicular spaces were retracted during inspiration, the chest moved scarcely at all, while the respiratory excursions of the abdomen were extreme. Respiration was rapid, and though inspiration seemed difficult, expiration was accomplished with the greatest effort and exertion, and was comparatively much 
prolonged. The pulse was 128 . The chest was hyperresonant, and on auscultation were heard diffusely scattered sibilant and occasional crackling râles. About the lieight of the attack the patient began to sweat about the head and face. At this time too, he began to cough, and expectorated a small quantity of thick bloodstained mucus. At 10:45 amyl nitrite was applied; at 10:53 1/100 gr. nitroglycerin inpodermatically. During the coughing spell he asked to hang his legs over the side of the bed. He did so, and at $11: 05$ the feeling of distress disappeared rapidly. The respirations continued, however, to be rapid, and at $11: 20$, fifteen minutes later, were 35, pulse 108. During the attack the blood-pressure rose from $200 \mathrm{~S} ., 70$ diastolic, to $247 \mathrm{~S}$, 70 diastolie, to fall in eleven minutes to $178 \mathrm{~S}$., 60 diastolic. At the end of the attack the râles had disappeared over the chest."

Such is the character of these paroxysms; short, lasting often from ten to fifteen minutes, but leaving the patient exhausted for an hour or two afterwards; agonizing, terrifying both to the patient and to the individual who sees him, usually accompanied by an increased pulserate, and a rise in blood-pressure that falls rapidly at the subsidence of the attack.

In the attack just described there was no pain, but in some cases there is pain, often excruciating, starting in the substernal region and radiating to the neck, left shoulder and down the left arm. In one case the pain radiated down the right arm. In the severest cases there is usually a cry for help at the start. Some patients remain almost jmmobile during the paroxyms, others wave their hands and arms about frantically. There is never an attempt to get out of bed or rush to the window. Often there is the for of impending death. Nitroglycerin has seemed to bring relief.

In the instances that I have watched the dyspnea was distinctly expiratory. The patient could not empty his lungs. During the attacks the chest became emphysematous, and auscultation revealed piping and occasional crackling râles. There was sweating and cyanosis. The attack ended with the expectoration of a little bloody mucus. The agony during some of these attacks is terrific. One patient in whom the dyspnea was associated with angina cut his throat. In two cases the attack itself was fatal.

The condition is very well known. Osler describes it most accurately, and speaks of the condition as one nearly allied to angina-angina of pulmonary type. Oigaard refers to it as Luft-Hunger, to the French it has long been familiar and Huchard terms it paroxysmal dyspnea; by the older authors it is referred to as cardiac asthma, and by some it has probably been considered as acute pulmonary edema. Breitmann calls particular attention to its significance in these cases. Though Huchard as well as many others would definitely exclude these cases from the category of angina pectoris, it is certainly difficult to say in some instances whether the patieni is suffering from an attack of angina pectoris with serere respiratory symptoms, or whether he is suffering with paroxysmal 
dyspnea with pain, for the attacks rary in different individuals from purely respiratory phenomenon, uninfluenced by exertion, and free from pain, to attacks in which the pain predominates, and in which the paroxysms are definitely associated with exertion. The attacks in their characteristic form simulate very closely a transient serere asthma, an extreme expiratory dyspnea with acute emphysema, and suggest very strongly that the direct eause of the dyspnea is bronchiospasm. The possible explanation of the phenomenon can best be discussed when we come to consider the effect of treatment on these symptoms of pain and respiratory distress.

Palpitation is of fairly common occurrence, and may occur early; with this there is sometimes tachycardia. With the derelopment of cardiac insufficiency in the cases of aortic regurgitation or of myocarditis, there naturally ensue the symptoms common to decompensation.

If aneurysm exists the special pressure symptoms dependent on the tumor make their appearance. In eleven of the twelve cases of aneurysm there was pain, usually constant, in the chest, left shoulder, neck and left arm.

As Allbutt has long pointed out, however, these symptoms described abore appear most frequently when the sigmoid region is involved, and this has been particularly true in my series. I have also noted that in the younger patients, pain and paroxysmal dyspnea have been most frequent. In seren patients over 50, who had aortic insufficiency, pain was entirely absent in two and very slight in three, the picture in these five cases being almost entirely that of gradual cardiac decompensation. In the remaining two cases there was severe pain and paroxysms of dyspnea.

Finally, it is necessary to mention the possible relationship between the syphilitic aortitis, and certain mexplained fevers in these cases. 'To this Popoffot has recently called attention. He reports three cases of aortic insufficiency with syphilitic aortitis in which there was an unexplained fever that disappeared rapidly after the administration of antisyphilitic treatment. In Bicrmamn's case of congenital syphilitic aortitis there was ferer. Though it is not uncommon to see slight fever or abnormally great variations in temperature in cases of aneurysm and aortic insufficiency with syphilitic aortitis, particularly just after admission to the hospital, it is difficult to exclude in such instances the presence of a slight bronchitis as a cause for the increased temperature. It is interesting, howerer, to note the effect of treatment on this temperature. In one of my cases of aortic insufficiency, there was a mild unexplained fever reaching at times $101 \mathrm{~F}$., which lasted for eleven days, but disappeared promptly after the first dose of salvarsan. In a second case, fever played a very prominent part in the picture.

67. Popoff: Ztsehr. f. klin. Med., 1912, lxxr, 5ec. 


\section{CASE REPOR'T}

A married woman aged 53 was admitted to the Presbyterian Hospital May 6 , 1912, complaining of general weakness. She had never been sick before. She had not had any children; the menopause had occurred four months previously. For six months she had been feeling badly, weak, and was losing weight. There had been no edema, no pain, no dyspnea, no cough. For six to eiglit weeks there lad been fever with night-sweats. She was an under-nourished, rather pale woman. In both conjunctivae there were small petechiae. The teeth were bad. The lungs were negative to examination. There was some enlargement of the heart, with a faint systolic murmur at the apex, and a donble murmur at the hase. The liver was palpable two fingers below the costal margin. The spleen could not be felt. There was no elema. The Widal was negative. Leukocytes 8,000; hemoglobin 75 per cent.; red blood-corpuseles 4,400,000; 5/11, von Pirquet negative; 5/13, Wassermann +++ (Noguchi). From time to time a few petechiae were noted over shoulders and back. Blood-cultures made $5 / 14$ and 5/28 gave no growth.

The course of the fever with the injections of salvarsan and Wassermann reactions are shown on the accompanying chart (Fig. 1).

June 13 the patient left the hospital much improved. As the fever did not entirely cease she consulted a physician, who treated her with intramuscular injections of salicylate of mercurr. By the middle of July she had improved still further, and was entirely fever-free. She remained af brile, but in September, 1912, suffered a severe break in compensation, from which she died Oct. 18, 1912.

It is of course possible to have an acute bacterial endocarditis or chronic infectire process engrafted on a syphilitic aortitis, and two such cases I have followed to antopsy. It is difficult to exclude in this case such a cause for the ferer, especially since there were petchiae, a feature so characteristic of subacute or chronic infective endocarditis. Bloodcultures, however, were constantly negative, while the complete disappearance of fever over a period of months would be unusual in infective endocarditis, unless the process had healed - as far as we know, an exceedingly rare occurrence. The gradual decline of fever and general improvement with the very persistent Wassermann reaction under treatment, together with the complete disappearance of fever with prolonged antisyphilitic treatment, suggest very strongly that the fever in this case was really dependent on the syphilitic infection of the aorta.

The early physical signs, unfortunately, are not numerous, and are sometimes difficult of detection, while the outspoken signs usually occur late in the disease.

The earliest, the most important, and the most constant single sign is a positive Wassermann reaction. It is now generally conceded that a positive Wassermann reaction in syphilis means active infection somewhere in the body (Boas ${ }^{68}$ ). And here I should like to call attention to the possibility and importance of syphilitic aortitis as a cause for positive Wassermann reactions in so-called latent syphilis. From the frequency with which syphilitic aortitis is found accidentally at autopsy, we know that the infection may be harbored in this situation for years withont

68. Boas: Di Wassermann'sche Reaktion, Berlin, 1910. 


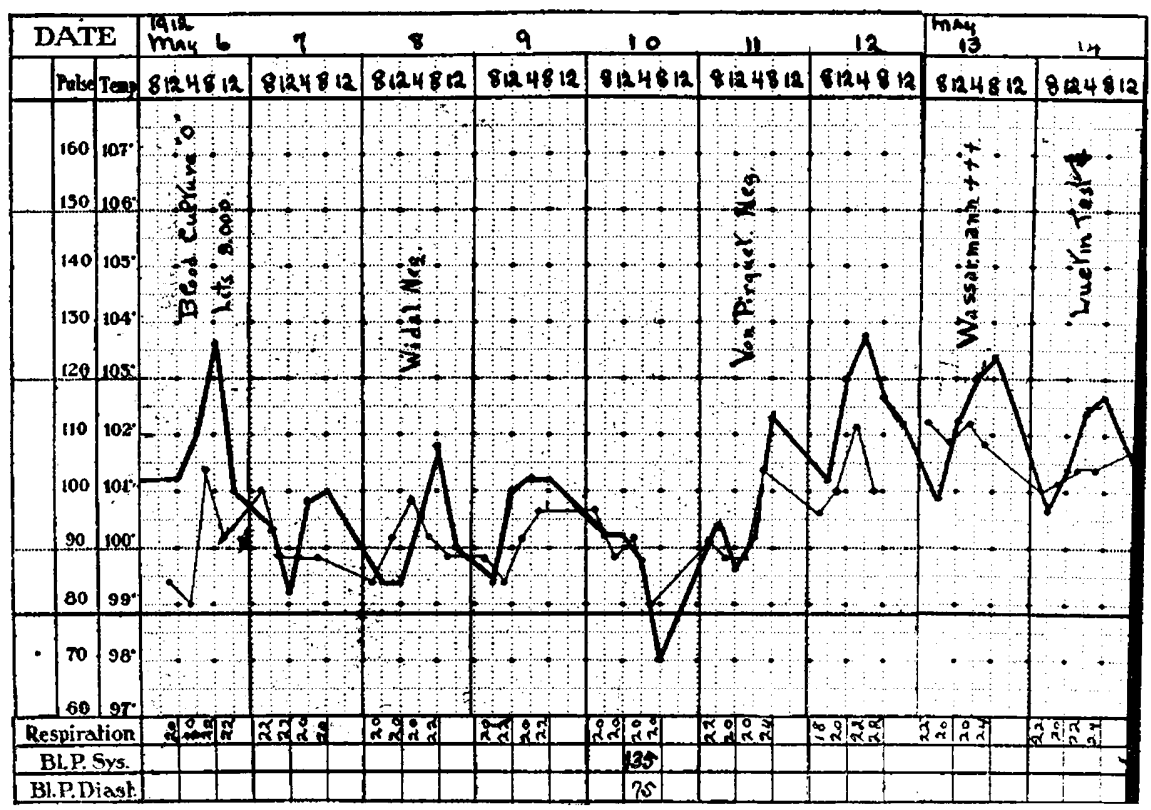

Figure 1.-Part 1.

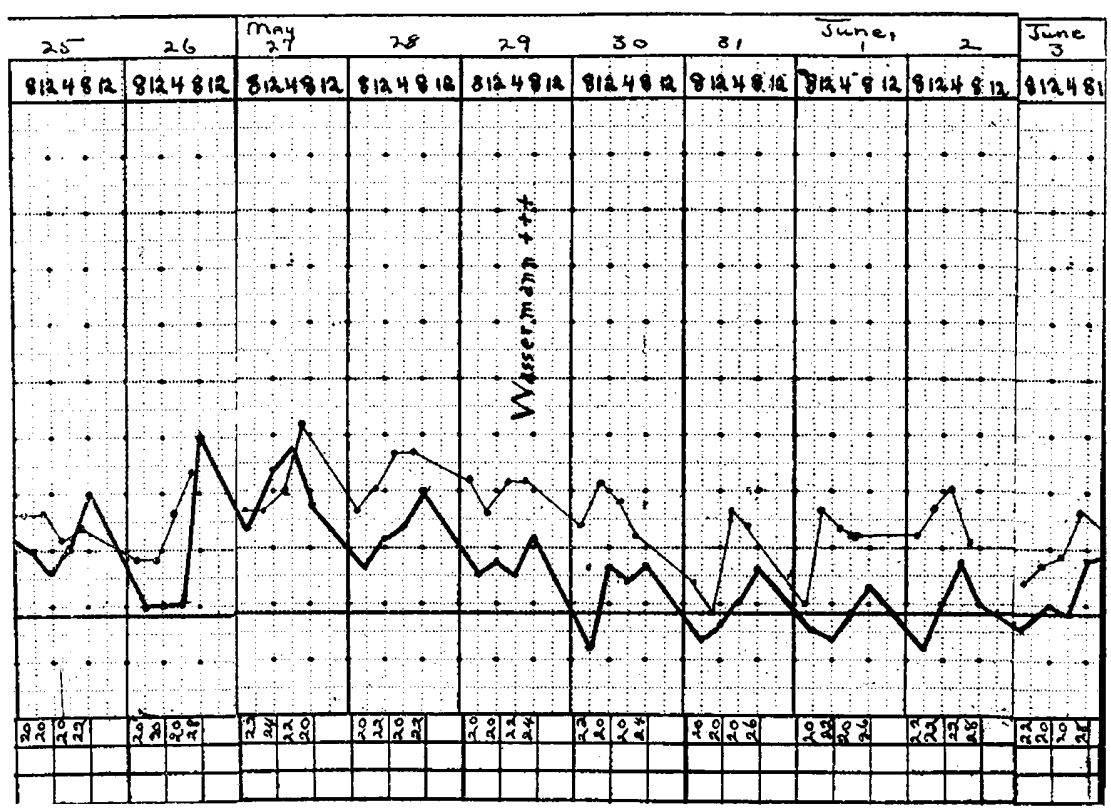

Figure 1.--Part 3.

Fig. 1.-Chart showing fever eurve and results of Wassermann test in the 


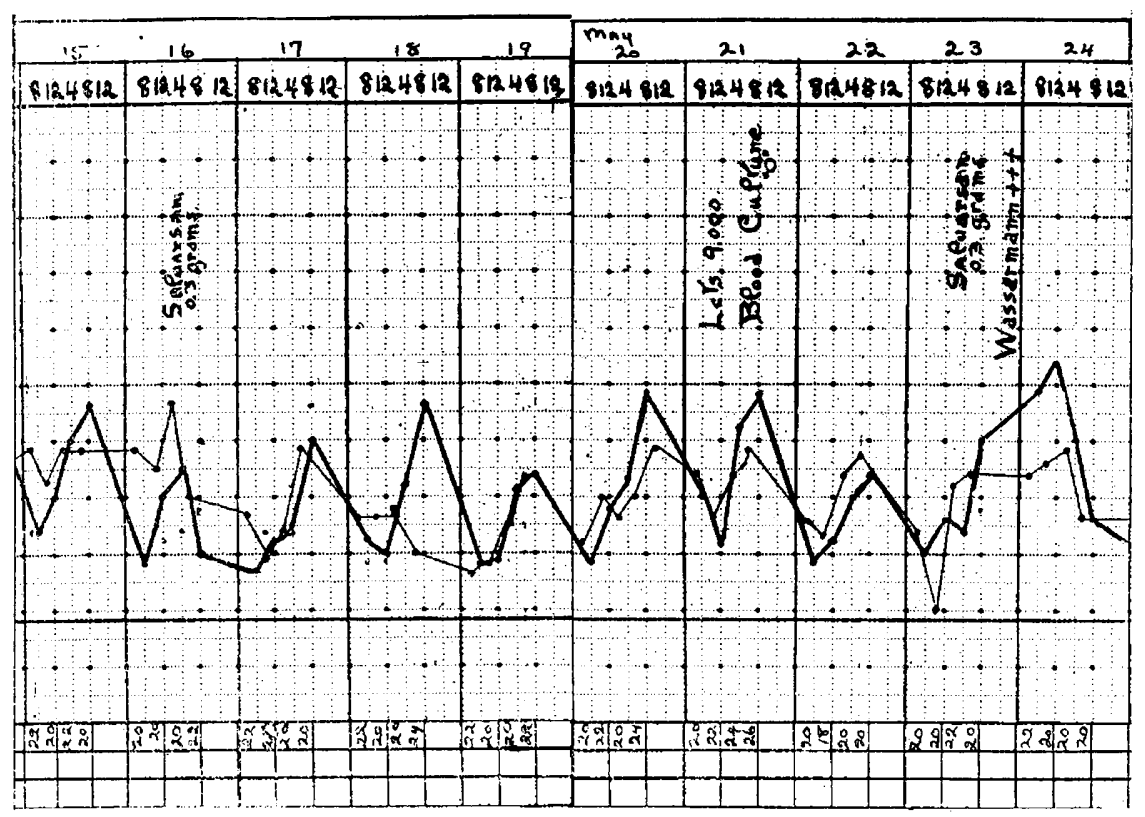

Figure 1.-Part 2.

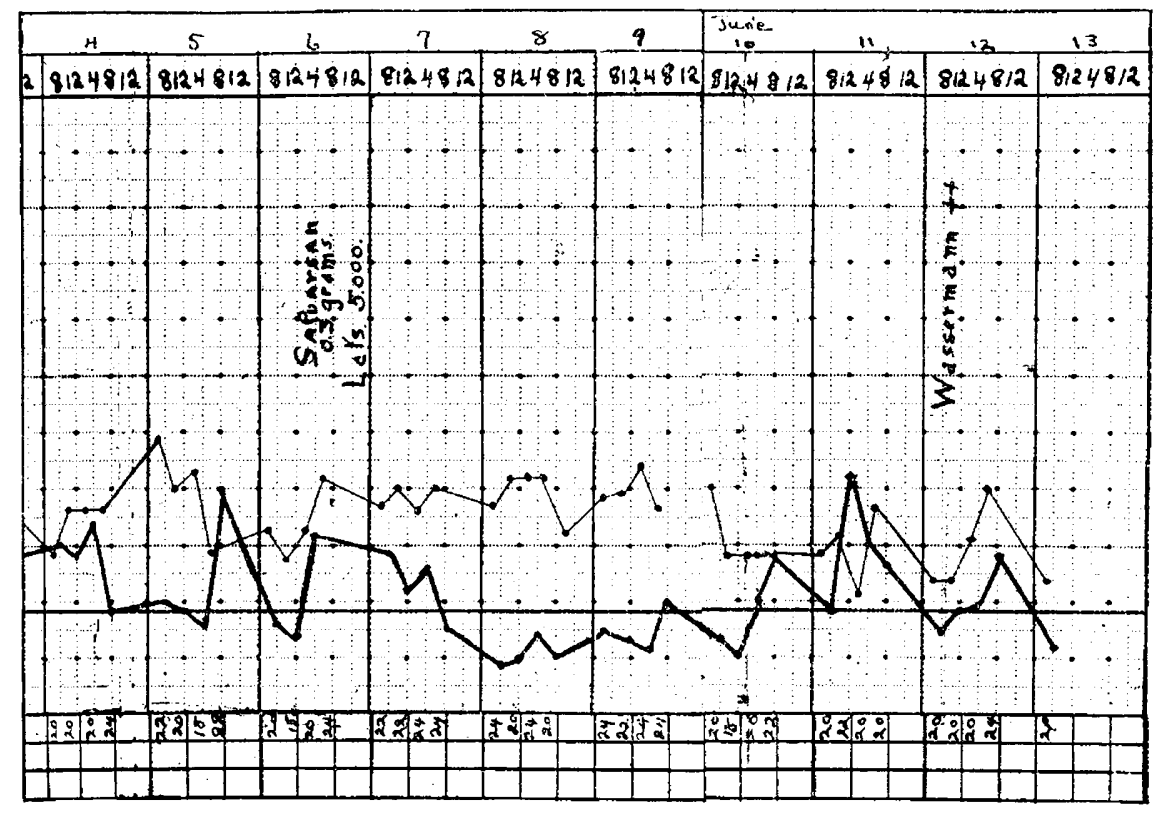

Figure 1.-Part 4.

case reported by the author. Heavy line $=$ temperature; light line $=$ pulse. 
detection during life, and indeed it seems as if the root of the aorta might be one of the chief situations in which the infection may lurk. Eich, in his pathological study of 63 cases of syphilitic aortitis, states that in 36, or over half, there were neither signs nor symptoms of the disease during life. One must nevertheless take exception to this statement, for in 9 cases the patients suftered from cardiovascular diseases. Excluding these 9 cases, howerer, there are still $2 \%$, or 42.8 per cent., in which the infection of the aorta was discovered by accident. In 24 out of 30 cases the Wassermann reaction was positive with post-mortem blood. I have now seen a number of cases in which a patch of syphilitic aortitis, wholly unsuspected until autopsy, was the only cause which could be found to explain a positive Wasscrmam reaction during life. 'This question, of course, needs further investigation before any definite statement can be made, but certainly the association is very striking, and probably very frequent. It is therefore of the utmost importance to investigate the cardiovascular system with the greatest care in all cases of so-called latent syphilis that give positive Wassermann reactions. The same statement naturally applies to the nervous system.

Next to the importance of the Wassermann reaction is the condition of the alorta itself. In a certain proportion of cases, but not in all, the lesion leads to a dilatation of the ascending aorta and arch. Dilatation is most common in the older and advanced cases. In 8 of our 35 autopsies there was no dilatation of the aorta. In two cases in which the patients are still living, $x$-ray examination showed no dilatation. In 25 cases, however, either the $x$-ray or autopsy disclosed a dilatation of varying gratle. This may be uniform or somewhat irregular. For a complete recent discussion of the symptomatology and diagnosis of aortic dilatation one should refer to McCrae's ${ }^{69}$ excellent article. One of the most prominent signs is an abnormal pulsation in the subclavian and carotid arteries with an impulse in the episternal notch. In marked instances there is a heave beneath the manubrium or pulsation in the first and second interspaces, usually to the right of the sternum, but sometimes to the left. The veins of the neck are often prominent. In a few instances I have noted a line of dilated veins extending in a semicircle from the first to the third or fourth ribs, and to the right of the sternum.

On palpation a pulsation is often felt in the episternal notch, oceasionally a heave and sometimes even a thrill over the manubrium. Percussion gives dulness over the sternum extending either to the right or left of the manubrium in the first and second interspaces. Auscultation very frequently reveals a systolic murmur at the aortic cartilage. The second sound is sharp, ringing, and has the bell-like quality so aptly emphasized by McCrac. This may be present, even in cases of aortic

69. McCrae: Am. Jour. Med. Sc., 1910, cxl, 469. 
insufficiency, whese the heart sound is acempanied or followed by a diastolic mumur. These sounds are frequently well transmitted over the upper sternal duluess, and beneath the clavicles, or even into the vessels of the neck. Pressure offects are sometimes noted. 'There may be a capillary and collapsing pulse even in the absence of an aortic insufficiency.

Of all the methorls of physical diagnosis, however, to determine whether or not dilatation exists, the $r$-ray is the most valuable. The orthodiagraph, as pointed out by Vaquez,,$^{70}$ gives undoubtedly a more arcurate pisture than the skiagram or fluoroscopic examination, but we

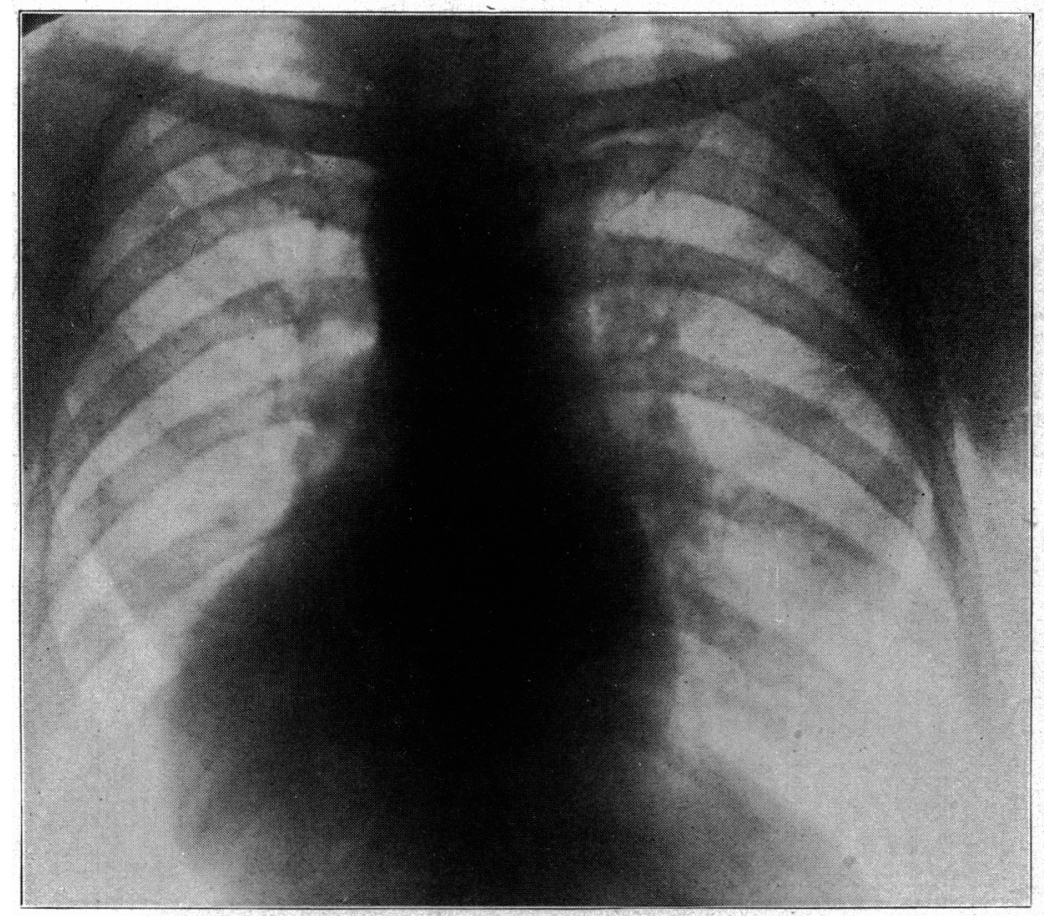

Fig. 2.- (ase 15. Angina pectoris and aortio insufficiency. Practically no dilatation.

have been obliged to confine omrelves to the latter methods. Fluoroscopy seems indispensable. Examinations have been made with the patient in the prone position, and lately it has seemed useful to examine the patient first with the sereen on the rhesi, and then on the back. In the latter prosition. When the pationt lies on his face the shadow of the heart is not very dear, but the outline of the areh and descending aorta is very distinct, and can be studied with much adrantage. 'The details of the (lianges in the size and shape of the aortic shadow when dilatation exists

70. Vaquez: Arch. d'éléctricité med., 1911, xii, 561. 


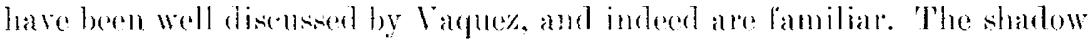
of the normal aorta as soen on the fluorescopic: sereen, or in the skiagram lies in its first portion behind the sternum, but at the areh where it corres mather shatply backwards and to the left, there is a well defined roumled knob, seen to the left of the sternum and opposite the second dorsal vertebra. Aceoding to the age of the patient and position of the

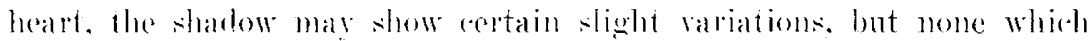
(an be confoumbed with definite dibatation (Fig. 2).

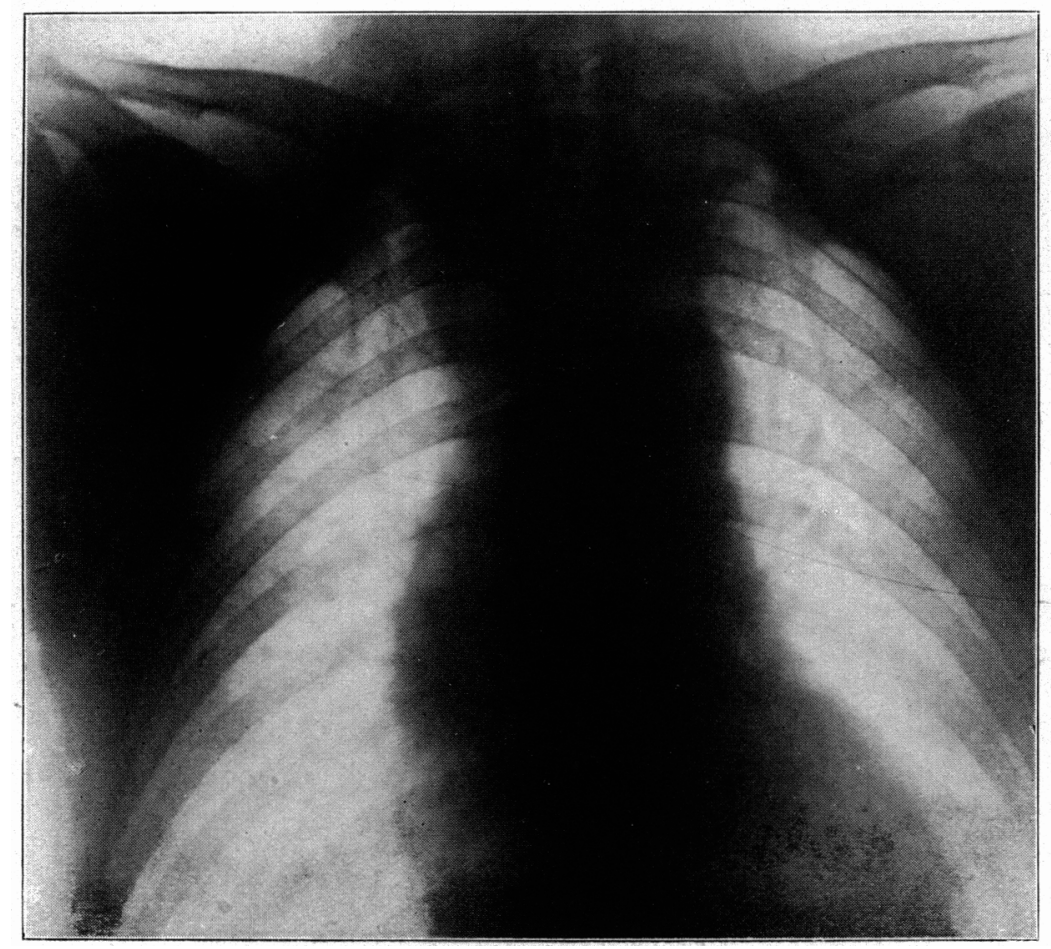

Fig. 3.-Case 14. Angina pectoris, systolic murmur at base and diffuse dilatation of aorta.

The eommonest changes that I have observed in dilatation are as pollows:

First, the andic shatow as it anernds from the heart shatlow is witened so that it projects in a corred line beyomel the sternum and

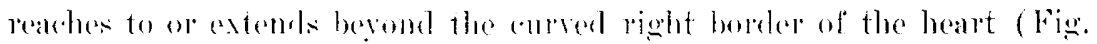
i). In most irstanes the onter shatow is rewular, but it may show

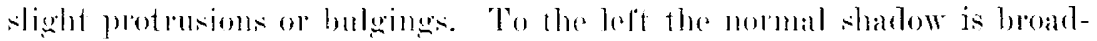
ened. 'Jhere may, ton, be Jeralizer irregularities on this outline. Ta a second group there are alterations of a more or less prominent character in the sharkow of the aortic knob, but since this represents the areh, it is 


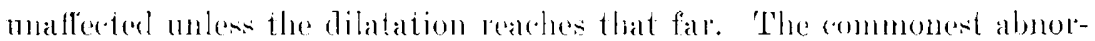
mality which has been observed is a gencral collarement with loss of the well-definet knob shape (Fig. 1), insters of which there is a resentie "ure towards the left. In other wases the knob may be enlarged, and its form more prominent than normal (Fig. i). Finally, in a thired group the aortic shadow appors more or less as a truncated cone with romoted apex and broad base resting on and fusing with the caldiace shatew. In sulth instances the normial anortic knob is obsculext.

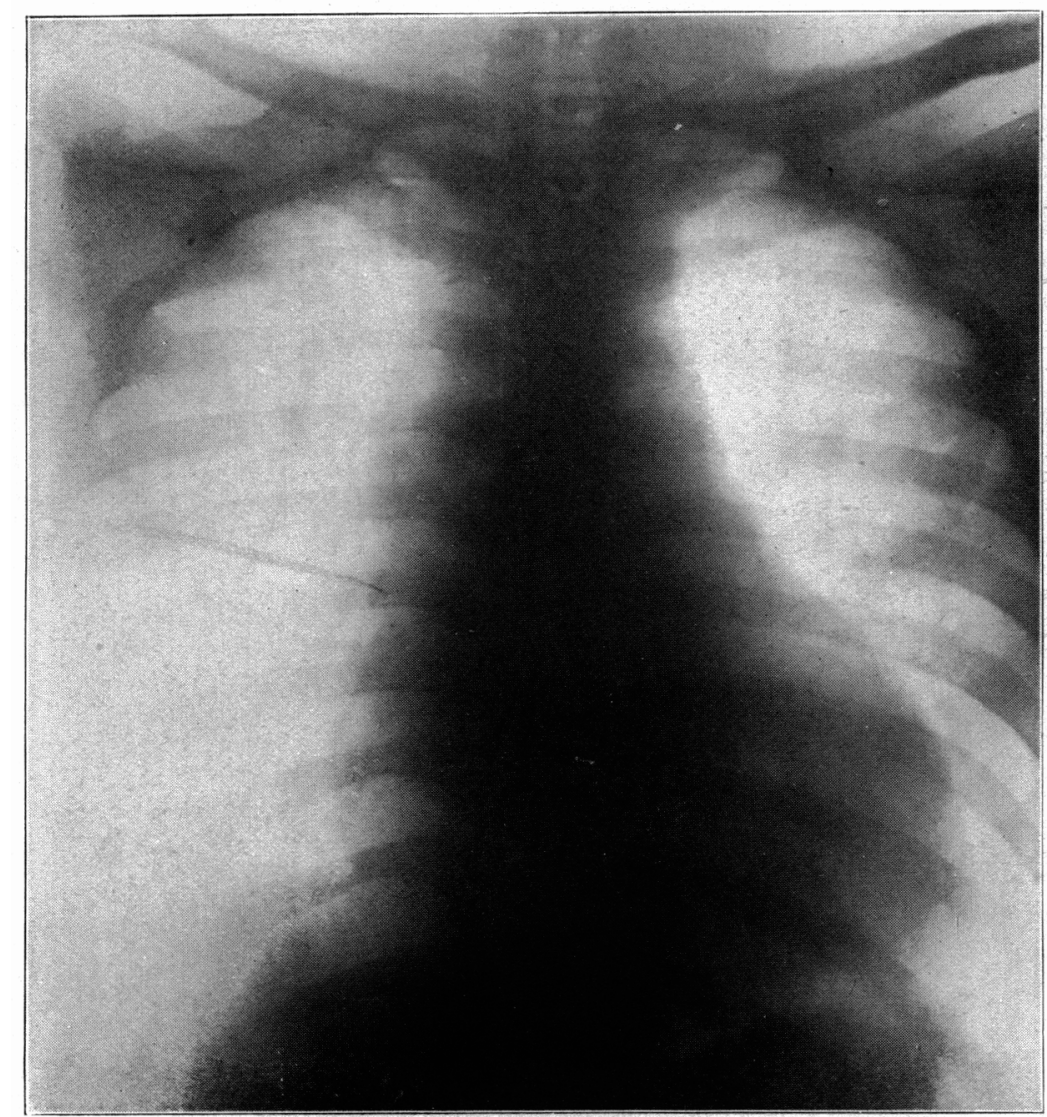

Fig. 4.-Case 10. Aortic insufficiency, paroxysmal dyspnea and diffuse carliac dilitation.

fo any instane. but best shown in Figure:?, there maly be above the antic shadow a pramiclal-shaped shadow with base mpwards, and beneath

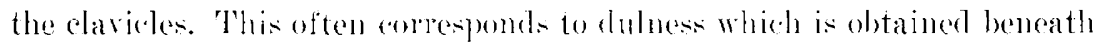
the sternal ends of the davicle. Compuring this shatow with the appearance of the structures in the superior mediastinum at antopsy, it seems to represent the dibated grat arteries as they arise lin the arch, and course 
upwards. In almost any case, but not frequently, the heart may assume a position more nearly horizontal than normal.

Though syphilitic aortitis commonly results in nore or less clilatation of the aorta, it is not of course the only cause, so that diffuse dilatation does not in itself form sufficient basis for a diagnosis. In aortic insufficiency following rheunatic fever there may be marked permanent dilatation without the presence of macroscopic lesions in the aorta, save perhaps a thimning of its walls.

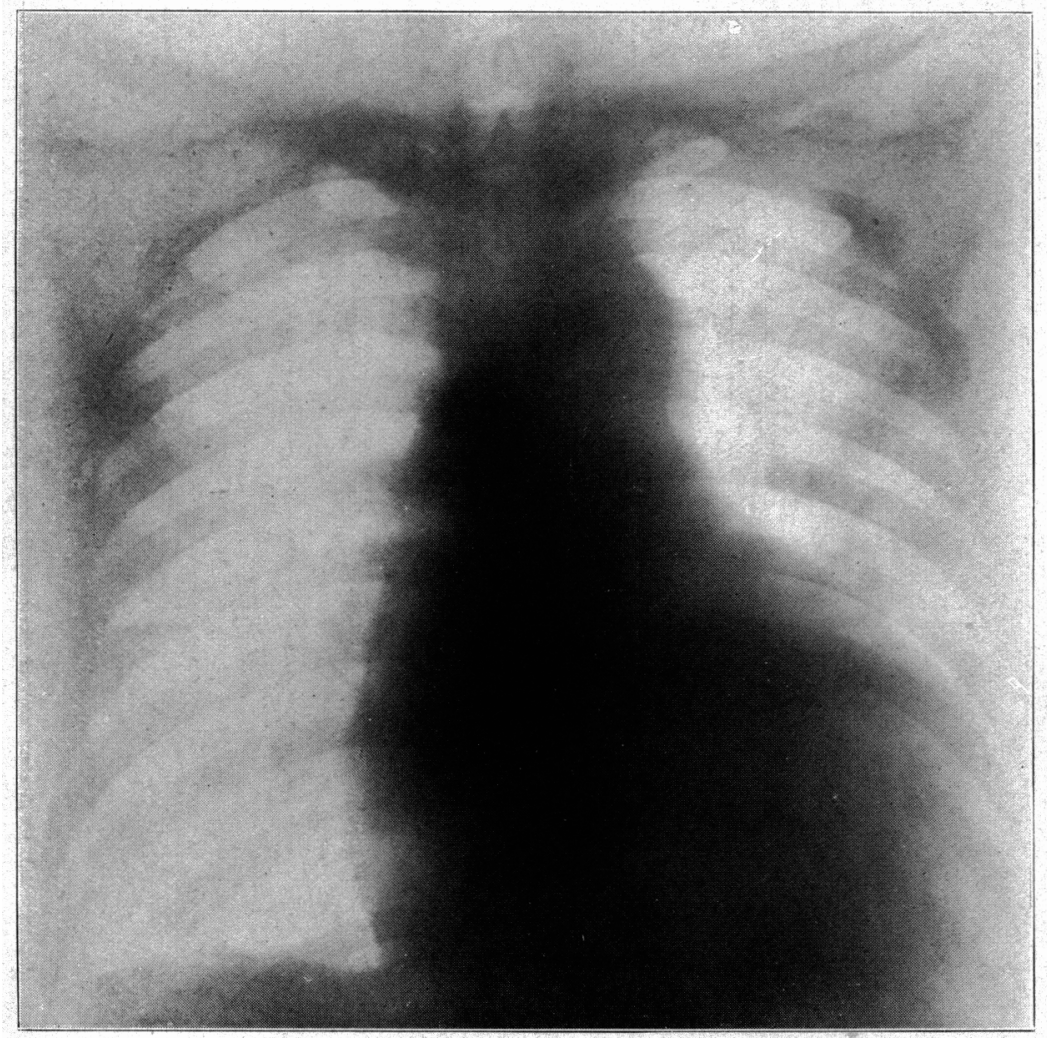

Fig. 5.-Case 11. Syplilitic aortitis; dilatation of aorta; prominence of aortic knob.

The importance of the presence of aortic insufficiency and aneurysu have been sufficiently emphasized; unfortunately they appear as a rule late in the disease.

Some increase in the size of the heart is usually found in all cases whether aortic insufficiency exists or not. With the marked enlargements there are as a rule ioud systolic murmurs at the apex. In one case, however, there existed only a presystolic gallop rhythm. 
The pulse in the majority of instances is regular, and we have not noted any characteristic qualities, though in one instance a markedly collapsing pulse and capillary pulse existed without any other signs of aortic iusufficiency. Occasionally the patches of aortitis, which not infrequently are situated about the mouths of the great vessels, become sufficiently extensive to narrow their lumen, or even to occlude them, in which event the pulse in the two radials or carotids show inequalities in size and force. In one case the pulse in the left common carotid was completely obliterated. Occlusion of the opening of the vessel was found at autopsy.

The prognosis, at least in cases which are seen in general hospitals, is bad. In 24 fatal cases in Bruce's series the average duration of life was 5.2 years. In my series there were 38 fatal cases. Of these, 4 patients succumbed to acute infertions not directly connected with the aortitis. In the remaining 34 , death took place in 23 , or in 67.6 per cent., within a year and a half of the onset of symptoms, and in 9 , or 26.4 per cent., within six months of onset of symptoms. The most rapid culmination took place in one case in a few weeks, 2 patients died within two months; the most prolonged case lasted about six years. Of the 25 patients who are known, or are supposed to be living, the disease has existed in 9 for two years, in 4 for three, in 4 for four, in 1 for five and in 4 for six years. Of the 38 fatal cases, 8 patients died suddenly in an attack of angina pectoris, or paroxysmal dyspnea, 3 died of acute infectious diseases, and the remainder succumbed to cardiac failure.

In some cases, particularly the advanced ones, the diagnosis is made with ease and certainty, but in others with the greatest difficulty. The commonest symptorns and signs are substernal pain, or angina pectoris; slight dyspnea on exertion, or attacks of paroxysmal dyspnea, evidence of a dilated aorta, and enlargement of the heart. A combination of any, or all of these with aortic insufficiency in a man or woman about or below middle life, is characteristic, while a positive Wassermann reaction assures the diagnosis in practically every instance. The mere presence of an aneurysm of the arch or root of the aorta presupposes in almost every instance syphilitic aortitis.

'The history of severe rheumatic ferer in a young man with aortic insufficiency, who gives a positive Wassermann reaction, may well lead to confusion, and unless pain or paroxysmal dyspnea be present, it would seem well-nigh impossible to come to any conclusion as to the etiology of the aortic lesion. I have seen two such cases in which an exact diagnosis could not be made. Since the Wassermann reaction is one of the most constant evidences, it may, and indeed should, be the first indication to put the physician on his guard, and suggest in cases of so-called latent syphilis the most careful examination of the cardiorascular system. 
Table of Collected Cases of Syphilitic Aortitis

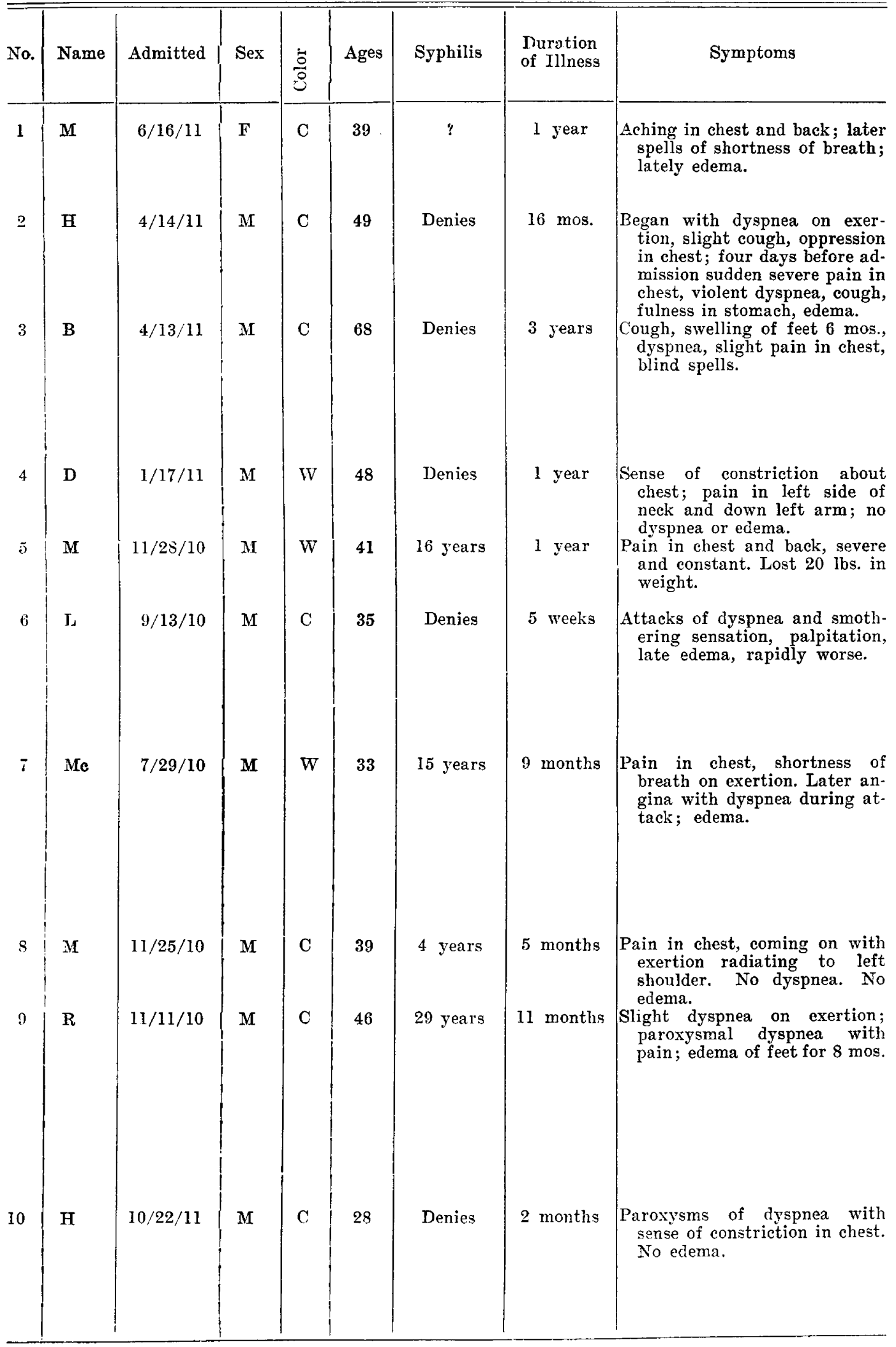


Table of Collected Cases of Sypintutic Aortitis-(Continued)

\begin{tabular}{|c|c|c|c|c|c|}
\hline Diagnosis & Wassermann & Salvarsan & Reaction & $\begin{array}{c}\text { Entire Dura- } \\
\text { tion of } \\
\text { Disease }\end{array}$ & Remarks \\
\hline $\begin{array}{l}\text { Aortic insufficiency; no } \\
\text { dulness over sternum. }\end{array}$ & $6 / 17+++$ & $\begin{array}{l}6 / 24, \quad 0.3 \mathrm{gm} . \\
\text { intraven. }\end{array}$ & None & $\begin{array}{l}1 \text { yr. } 8 \text { mos. } \\
\text { Dead }\end{array}$ & $\begin{array}{l}\text { Death, Feb. } 12,1912 \text {. No } \\
\text { autopsy. Slight imp.; } \\
\text { ret u r n of symptoms } \\
\text { later, with pain. }\end{array}$ \\
\hline $\begin{array}{l}\text { Aortic insufficiency, car- } \\
\text { diac insufficiency, dif- } \\
\text { fuse dilatation of aorta } \\
x \text {-ray. }\end{array}$ & $\begin{array}{l}4 / 20+++ \\
5 / 24 \text { neg. }\end{array}$ & 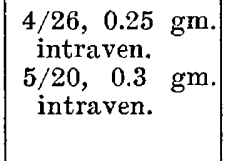 & $\begin{array}{l}\text { None } \\
\text { None }\end{array}$ & 1 yr. 10 mos. & $\begin{array}{l}\text { Marked improvement. } \\
\text { Temporary loss of pain. } \\
\text { Able to work again; } 6 \\
\text { mos. later decompensa- } \\
\text { tion without pain. }\end{array}$ \\
\hline $\begin{array}{l}\text { A ortic insufficiency, } \\
\text { broken cardiac compen- } \\
\text { sation. }\end{array}$ & $\begin{array}{l}4 / 18+++ \\
5 / 24+++ \\
6 / 7++ \\
6 / 21++\end{array}$ & $\begin{array}{ccc}4 / 28, & 0.3 & \mathrm{gm} \\
\text { intraven. } \\
5 / 20,0.3 & \mathrm{gm} . \\
\text { intraven. } \\
6 / 10,0.3 & \mathrm{gm} . \\
\text { intraven. } & \end{array}$ & $\begin{array}{l}\text { None } \\
\text { Chill } \\
\text { Nausea }\end{array}$ & 3 years $+?$ & $\begin{array}{l}\text { Improvement marked, } \\
5 / 20, \text { pain in chest } \\
\text { gone, 5/26, has pain in } \\
\text { chest. Decomp. impr'd } \\
\text { on rest and dig. Left } \\
\text { hosp. feeling well, pain } \\
\text { gone. }\end{array}$ \\
\hline $\begin{array}{l}\text { Dilatation of aorta }(x- \\
\text { ray); slight aortic re- } \\
\text { gurgitation, enlarged } \\
\text { liver, anginal pain. }\end{array}$ & $1 / 24+++$ & $\begin{array}{l}2 / 10,0.6 \mathrm{gm} . \\
\text { intramuse. }\end{array}$ & Fever & $\begin{array}{l}2 \text { yr. } 10 \text { mos. } \\
\text { +. Living }\end{array}$ & $\begin{array}{l}\text { Much improved. Aug. '12, } \\
\text { working hard; feel } \\
\text { well. }\end{array}$ \\
\hline $\begin{array}{l}\text { Dilatation of aorta }(x- \\
\text { ray). Heart normal; } \\
\text { anginal pain. }\end{array}$ & $\begin{array}{l}1 / 30++ \\
2 / 15-\end{array}$ & $\begin{array}{l}12 / 8,0.6 \mathrm{gm} \\
\text { intramuse. }\end{array}$ & Slight & 3 yrs. + & $\begin{array}{l}\text { Greatly imp. Perm. (?) } \\
\text { Gained wgt.; Aug. 1: } \\
\text { working as fireman. }\end{array}$ \\
\hline $\begin{array}{c}\text { Aortic insufficiency. Dila- } \\
\text { tation of aorta, severe } \\
\text { broken compensation. }\end{array}$ & $10 / 14++t$ & $11 / 14,0.45 \mathrm{gm}$. & Local & 5 months & $\begin{array}{l}\text { Very slight temporary } \\
\text { improvement. Sudders } \\
\text { death. Autopsy. Syph- } \\
\text { ilitic aortitis involving } \\
\text { aortic valves, pseudo- } \\
\text { lobar pneumonia. Sec- } \\
\text { tions of aorta do not: } \\
\text { differ from other cases. }\end{array}$ \\
\hline $\begin{array}{l}\text { Aortic insufficiency. Dila- } \\
\text { tation of aorta ( } x- \\
\text { ray); very s light } \\
\text { edema; angina pec- } \\
\text { toris; S. P. } 170 ; \text { D. } 70 .\end{array}$ & $9 / 16+t+$ & $\begin{array}{l}11 / 21,0.45 \mathrm{gm} \\
\text { intramusc. }\end{array}$ & Local & 1. yr. Deatl & $\begin{array}{l}\text { Marked temp. imp. An } \\
\text { ginal attacks } 3-4 \text { times } \\
\text { daily before salvarsan. } \\
\text { Two wks. after treatm. } \\
\text { much better. Sometimes } \\
\text { only one attack in } 3 \text { or } \\
4 \text { days. By } 12 / 28 \text {, recur- } \\
\text { rence. Suicide.Autopsy: } \\
\text { Dilatation of aorta } \\
\text { aortic insufficiency. }\end{array}$ \\
\hline $\begin{array}{l}\text { Aortic insufficiency; an- } \\
\quad \text { gina pectoris; S. P. } \\
\text { 120; D. } 80 .\end{array}$ & $\begin{array}{l}11 / 30+++ \\
12 / 21++ \\
1 / 10 / 11++ \\
2 / 7++\end{array}$ & $\begin{array}{l}11 / 30,0.6 \mathrm{gm} \\
\text { intramusc. }\end{array}$ & Local & $\begin{array}{l}8 \text { mos. } \\
\text { Dropped } \\
\text { dead }\end{array}$ & $\begin{array}{l}\text { No definite relief from } \\
\text { angina. Death, } 2 / 13 \text {. } \\
\text { 1911. }\end{array}$ \\
\hline $\begin{array}{l}\text { Aortic insufficiency. Par. } \\
\text { oxysmal dyspnea with } \\
\text { pain. Broken compen- } \\
\text { sation. S. P. 17S. D. } 90 .\end{array}$ & $\begin{array}{l}11 / 14+++ \\
12 / 21++ \\
1 / 10+ \\
2 / 28+ \\
3 / 3+ \\
3 / 24+ \\
4 / 12++\end{array}$ & $\left\{\begin{array}{l}11 / 16,0.5 \mathrm{gm} \\
\text { intramuse. }\end{array}\right.$ & Local & $\begin{array}{l}1 \text { yr. } 5 \text { mos. } \\
\text { Death } \\
\end{array}$ & $\begin{array}{l}\text { Marked temp. imp. Before } \\
\text { treatment, a t a cks } \\
\text { every day and night } \\
\text { for il mos. For } 2 \text { weeks } \\
\text { after, oce. attack. Ther } \\
\text { for } 2 \text { whs. recurrence } \\
\text { followed by complete } \\
\text { freedom with ability to } \\
\text { get about for } 2 \text { mos. } \\
\text { Later recur. with deatl. }\end{array}$ \\
\hline $\begin{array}{l}\text { Aortic insufficiency. Dila- } \\
\text { tation of aorta (x-ray). } \\
\text { Paroxysmal dyspnea } \\
\text { Slight fever. S. P. 118. } \\
\text { D. 82. }\end{array}$ & $\begin{array}{c}\text { Noguchi } \\
10 / 26+++ \\
11 / 1+++ \\
11 / 8+++ \\
11 / 15+++\end{array}$ & $\left|\begin{array}{ccc}11 / 2, & 0.3 & \mathrm{gm} \\
\text { intravell. } \\
11 / 13,0.3 & \mathrm{gm} . \\
\text { intraven. } & \\
11 / 22, \quad 0.3 & \mathrm{gm} .\end{array}\right|$ & $\begin{array}{l}\text { None } \\
\text { None } \\
\text { None }\end{array}$ & $\underset{\text { ing }}{\mathbf{y r} .+\mathrm{Liv}-}$ & $\begin{array}{l}\text { Improvement permanent. } \\
\text { Complete disappear- } \\
\text { ance of paroxysmal } \\
\text { dyspnea and fever. } \\
\text { Well Nov., } 1912 \text {. }\end{array}$ \\
\hline
\end{tabular}


Table of Collected Cases of Syphilitic Aobtitis-(Continued)

\begin{tabular}{|c|c|c|c|c|c|c|c|c|}
\hline No. & Name & Admitted & Sex & $\frac{\dot{0}}{\dot{\theta}}$ & Ages & Syphilis & $\begin{array}{l}\text { Duration } \\
\text { of Illness }\end{array}$ & Symptoms \\
\hline 11 & $\mathrm{~N}$ & $11 / 8 / 11$ & $M$ & $\mathrm{C}$ & 40 & 20 years & 5 years & $\begin{array}{l}\text { Pain in chest, acute, radiating } \\
\text { to left arm; 1 yr. shortness } \\
\text { of breath on slight exertion; } \\
\text { edema, cough. }\end{array}$ \\
\hline 12 & $\mathbf{N}$ & $12 / 1 / 11$ & MI & W & 61 & Denies & 6 years & $\begin{array}{l}\text { Palpitation; slight dyspnea; } \\
\text { angina pectoris. }\end{array}$ \\
\hline 13 & $\mathbf{T}$ & $12 / 17 / 11$ & M & W & 47 & 28 years & 9 months & $\begin{array}{l}\text { Pain in chest at first. Two vio- } \\
\text { lent attacks of dyspnea; pal- } \\
\text { pitation, general weakness, no } \\
\text { edema. }\end{array}$ \\
\hline 14 & B & $3 / 2 / 12$ & $\mathbf{M}$ & WV & 51 & 25 years & $2-3$ years & $\begin{array}{l}\text { Dyspnea slight on exertion. An- } \\
\text { gina pectoris for } 1 \text { year. }\end{array}$ \\
\hline 15 & $\mathbf{T}$ & $3 / 20 / 12$ & $\mathbf{M}$ & WV & 36 & 19 years & 1 year & $\begin{array}{l}\text { Angina pectoris on exertion or } \\
\text { excitement. }\end{array}$ \\
\hline 17 & W & $5 / 6 / 12$ & M & $\mathrm{IT}$ & 53 & Denies & 6 months & $\begin{array}{l}\text { For } 4 \text { mos. attacks of dyspnea, } \\
\text { pain over heart radiating to } \\
\text { left shoulder; } 3 \text { wks., edema. } \\
\text { One transient attack of blind- } \\
\text { ness. } \\
\text { Weakness, loss of weight, fever. }\end{array}$ \\
\hline is & $\mathrm{C}$ & $9 / 9 / 12$ & $F$ & C & 38 & + & 6 months & $\begin{array}{l}\text { Palpitation, shortness of breath, } \\
\text { pain over heart, occasionally } \\
\text { attacks of dyspnea at night. }\end{array}$ \\
\hline 19 & L & $0 / 1.1 / 12$ & F & W & 39 & ? & 9 months & $\begin{array}{l}\text { Attacks of angina with dvsp- } \\
\text { nea on exertion; } 5 \text { dars } \\
\text { edema. }\end{array}$ \\
\hline 20 & $\mathrm{Me}$ & $8 / 31 / 12$ & MI & $\mathrm{W}$ & 50 & 9 years & 8 months & $\begin{array}{l}\text { Dull pain in left shoulder, con- } \\
\text { stant; later down left arm: } \\
\text { mos. dyspnea; } 1 \text { mo. apho- } \\
\text { nia. }\end{array}$ \\
\hline
\end{tabular}


Table of Collected Cases of Syphilitic Aortitis-(Continued)

\begin{tabular}{|c|c|c|c|c|c|}
\hline Diagnosis & Wassermann & Salvarsan & Reaction & $\begin{array}{c}\text { Entire Dura- } \\
\text { tion of } \\
\text { Disease }\end{array}$ & Remarks \\
\hline $\begin{array}{l}\text { Dilatation of aorta }(x- \\
\text { ray), a ng i n a l pain, } \\
\text { broken compensation, } \\
\text { enlarged heart with mi- } \\
\text { tral insufficiency. S. P. } \\
105 . \text { D. } 65 .\end{array}$ & $\begin{array}{l}11 / 15+++ \\
12 / 8- \\
1 / 26- \\
3 / 22-\end{array}$ & \begin{tabular}{|cc}
$11 / 24,0.3$ & $\mathrm{gm}$ \\
intraven. \\
$12 / 1,0.3$ \\
intraven. \\
$12 / 8,0.3$ \\
intraven. \\
int. \\
$\begin{array}{c}12 / 16,0.3 \\
\text { intraven. }\end{array}$
\end{tabular} & $\begin{array}{l}\text { None } \\
\text { None } \\
\text { None } \\
\text { None }\end{array}$ & $6 \underset{\text { yrs. }}{\text { Living }}+$ & $\begin{array}{l}\text { Complete disappearance } \\
\text { of pain. Repeated at- } \\
\text { tacks of broken com- } \\
\text { pensation. Doing fairly } \\
\text { well. }\end{array}$ \\
\hline $\begin{array}{l}\text { Angina pectoris. No dila- } \\
\text { tation of aorta }(x \text {-ray }) \text {. } \\
\text { S. P. 150. D. } 104 \text {. }\end{array}$ & $12 / 10++$ & $\left\{\begin{array}{c}12 / 29, \quad 0.3 \mathrm{gm} \\
\text { intraven. }\end{array}\right.$ & Slight & $\begin{array}{l}6 \text { yr's. } 6 \text { mos. } \\
+ \text { Living }\end{array}$ & $\begin{array}{l}\text { Greatly improved. Still } \\
\text { doing well. }\end{array}$ \\
\hline $\begin{array}{l}\text { Aortic insufficiency. An- } \\
\text { eurysm of areh of aorta } \\
(x \text {-ray }) . \quad \text { S. P. } 184 . \\
\text { D. } 70 .\end{array}$ & $\begin{array}{l}12 / 8+++ \\
12 / 20++ \\
1 / 12- \\
8 / 20-\end{array}$ & $\begin{array}{l}\text { 12/ } 8,0.3 \mathrm{gm} . \\
\text { intraven. } \\
12 / 15,0.3 \mathrm{gm} . \\
\text { intraven. } \\
\text { In next mo. } 2 \\
\text { doses } 0.3 \mathrm{gm} . \\
\text { intraven. }\end{array}$ & Slight & 1 yr. 6 mos. & $\begin{array}{l}\text { Improved. No symptoms. } \\
\text { Gained strength. Symp- } \\
\text { tomatically well. }\end{array}$ \\
\hline $\begin{array}{l}\text { Dilatation of arch of } \\
\text { aorta ( } x \text {-ray); systolic } \\
\text { murmur at base; slight } \\
\text { cardiac hypertrophy; } \\
\text { tabes dorsalis: angina. } \\
\text { S. P. 130. D. } 90 \text {. }\end{array}$ & $\begin{array}{l}3 / 28+++ \\
4 / 3++\end{array}$ & \begin{tabular}{|cc}
$3 / 28,0.2$ & $\mathrm{gm}$ \\
intraven. \\
$4 / 5,0.3$ & $\mathrm{gm}$. \\
intraven. & \\
$4 / 14,0.3$ & $\mathrm{gm}$.
\end{tabular} & $\begin{array}{l}\text { None } \\
\text { None } \\
\text { None }\end{array}$ & $\begin{array}{l}3 \text { yrs. } \\
\text { Living }\end{array}$ & $\begin{array}{l}\text { Well up to the present } \\
\text { time; working. }\end{array}$ \\
\hline $\begin{array}{l}\text { Aortic insufficiency. No } \\
\text { dilatation of arch }(x- \\
\text { ray). Angina pectoris. }\end{array}$ & $\begin{array}{l}5 / 23++ \\
5 / 29-? \\
6 / 13 \pm \\
9 / 11+++\end{array}$ & $\begin{array}{ccc}5 / 23,0.3 & \mathrm{gm} \\
\text { intraven. } & \\
5 / 29,0.3 & \mathrm{gm} . \\
\text { intraven. } & \\
\text { 6/ } 6,0.3 & \mathrm{gm} . \\
\text { intraven. } \\
6 / 20,0.3 & \mathrm{gm} . \\
\text { intraven. } & \\
7 / 15,0.6 & \mathrm{gm} . \\
\text { intraven. } & \\
9 / 13,0.6 & \mathrm{gm} . \\
\text { intraven. } & \\
9 / 25,0.6 & \mathrm{gm} .\end{array}$ & $\begin{array}{l}\text { None } \\
\text { None } \\
\text { None } \\
\text { None } \\
\text { None } \\
\text { Vomiting }\end{array}$ & $\mid \begin{array}{l}1 \text { yr. } 5 \text { mos. } \\
\text { Dead }\end{array}$ & $\begin{array}{l}\text { Improvement with tempo- } \\
\text { rary cessation of at- } \\
\text { tacks after each dose. } \\
\text { Herxheimer reaction. } \\
\text { Sudden death Oct. } 1,1912\end{array}$ \\
\hline $\begin{array}{ll}\text { Aortic insufficiency: aor- } \\
\text { tic dilatation } & (x \text {-ray) } \\
\text { Paroxysmal } & \text { dyspnea } \\
\text { with pain. } & \text { S. P. } 186 . \\
\begin{array}{ll}\text { D. } 58 . & \end{array}\end{array}$ & $6 / 23+t+$ & $\begin{array}{l}8 / 24,0.3 \mathrm{gm} . \\
\text { intraven. }\end{array}$ & Slight & 4 mos. Death & $\begin{array}{l}\text { Sudden death within } 48 \\
\text { hours of salvarsan. }\end{array}$ \\
\hline $\begin{array}{l}\text { Aortic insufficiency; fe- } \\
\text { ver; anemia. }\end{array}$ & $\begin{array}{l}5 / 11+++ \\
5 / 23+++ \\
5 / 29+++ \\
6 / 12++\end{array}$ & $\begin{array}{ll}5 / 16,0.3 & \mathrm{gm} \\
\text { intraven. } \\
5 / 23,0.3 & \mathrm{gm} . \\
\text { intraven. } \\
6 / 6,0.3 & \mathrm{gm} . \\
\text { intraven. }\end{array}$ & $\begin{array}{c}\text { None } \\
\text { None } \\
\text { Vomited }\end{array}$ & $\begin{array}{l}11 \frac{1}{2} \operatorname{mos} . \\
\text { Death }\end{array}$ & $\begin{array}{l}\text { Moderate improvement. } \\
\text { Loss of fever after in- } \\
\text { jections of } \mathrm{Hg} \text {. Death } \\
\text { Oct. } 12 \text {, } 1912 \text {, of car- } \\
\text { diac decompensation. }\end{array}$ \\
\hline $\begin{array}{l}\text { Aortic insufficiency; dila- } \\
\text { tation of aorta. S. P. } \\
\text { 165. D. } 60 \text {. }\end{array}$ & $9 / 13+++$ & $\begin{array}{l}9 / 19, \quad 0.3 \mathrm{gm} . \\
\text { intraven. }\end{array}$ & Fever & 6 mos. Liv- & $\ldots \ldots \ldots \ldots \ldots \ldots$ \\
\hline $\begin{array}{l}\text { Aortic insufficiency; dila- } \\
\text { tation of arch (x-ray) } \\
\text { Attacks of angina and } \\
\text { dyspnea. S. P. } 155 . \\
\text { D. 50. }\end{array}$ & $9 / 20+++$ & 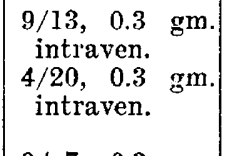 & $\begin{array}{l}\text { None } \\
\text { Slight }\end{array}$ & 9 mos. Tiv- & $\begin{array}{l}\text { Improvement. For } 4 \text { days } \\
\text { before salvarsan } 7 \text { at- } \\
\text { tacks. In next week } 2 \\
\text { attacks. }\end{array}$ \\
\hline $\begin{array}{l}\text { Aneurysm of aorta }(x- \\
\text { ray); differences in } \\
\text { pulses; paralysis of left } \\
\text { vocal cord; pressure on } \\
\text { left bronchus. }\end{array}$ & $\begin{array}{l}9 / 6+++ \\
9 / 13++\end{array}$ & $\begin{array}{ccc}9 / 7, \quad 0.3 & \mathrm{gm} \\
\text { intraven. } \\
9 / 13,0.3 & \mathrm{gm} . \\
\text { intraven. } & \\
\text { 9/20, } 0.3 & \mathrm{gm} . \\
\text { intraven. } & \\
\text { 9/28, } 0.3 & \mathrm{gm} . \\
\text { intraven. } & \\
\text { 10/ } 8,0.3 & \mathrm{gm} .\end{array}$ & $\begin{array}{l}\text { None } \\
\text { N'nne } \\
\text { Slight }\end{array}$ & $8 \underset{\text { mos. Liv }}{\text { ing }}$ & No improvement. \\
\hline
\end{tabular}


TREATMIENT

Since the recognition of the syphilitic origin of certain cardiovascular diseases, antisyphilitic treatment has been recommended and used with varying degrees of success (Huchard, Fournier, Osler, Allbutt). It is usually stated that such treatment may bring about relief from pain. Within the last few years, however, more particular attention has been paid to the treatment of these cases. Goldscheider thinks that the outlook is poor. Potassium iodid is insufficient and must be combined with mercury or salvarsan. Oigaard, on the other hand, reports rather satisfactory results with the use of mercury and iodid. In this manner he has treated fifteen patients with marked improvement in all cases. This benefit showed itself by the disappearance of substernal pain, angina and paroxysmal dyspnea, in increasing strength and returning ability to work, and an improvement in the anemia when this was present. The relationship which he found to exist between the Wassermann reaction and disappearance of symptoms is interesting. In six cases the Wassermann test became negative during the first cure, which lasted about three months; in the remaining cases the reaction disappeared more slowly, and only after two or three courses of treatment. In three instances there was a return of symptoms while the Wassermann was still negative, while in four the symptoms disappeared before the Wassermann.

With the introduction of salvarsan, Ehrlich's original warning against the use of this drug in the presence of cardiovascular disease prevented for some time its employment in syphilitic aortitis, but now sufficient data have accumulated to show that the danger under such conditions is slight. Breitmann, who collected the cases of death after salvarsan injections, reported in the literature, has discussed this question quite fully from a theoretical standpoint. He thinks the drug may prove dangerous when there is disease of the coronary arteries.

The experimental work of Aueri1 has shown that salvarsan injected intravenously in acid solution is dangerous. Rabbits and dogs injected intravenously with 0.5 per cent. acid solutions develop cardiac dilatation, and show abrupt fall in blood-pressure with immediate death. The intravenous injection of 0.5 per cent. alkaline solution in dogs seems to have little effect on the blood-pressure, and no marked effect on the heart, though its factor of safety may be so reduced in some instances that an extra strain brings on fibrillation and death. With higher dilutions of the drug, even acid solutions may be harmless when injected slowly. The alkaline solution employed by Auer is five times as strong as that used for man in whom 0.1 per cent. solutions are employed. Hoke and Rihl, ${ }^{72}$

71. Auer: Time Archives Int. Med., I911, viii, 169; Jour. Exper. Med., 1911, xiv, 248.

72. Hoke and Rihl: Ztschr. f. exper. Path. u. Therap., 1911, ix, 332. 
who experimented with intravenous injections of 0.5 per cent. salvarsan in alkaline solution state that such a solution will lower the blood-pressure in rabbits, but that this is principally due to its effect on the central nervous system, and not on the heart and blood-vessels directly.

From a practical standpoint the use of salvarsan in syphilitic aortitis seems to be comparatively harmless, though later I will point out a possible source of danger when large doses are given; and the main point at issue is as to whether it is of real benefit. Weintraud ${ }^{56}$ has reported the results of treatment by salvarsan of twenty-six cases of syphilitic heart and arterial disease. The cases included aortic insufficiency, angina pectoris, myocardial disease with syphilitic arteritis and sclerosis of the cerebral arteries. He has not seen any ill effects from the injections. Two to four injections of 0.2 to 0.5 gram were given. In many of the cases there were no symptoms, or where symptoms were present they were so mild that any benefit derived from the injections could not be estimated. In only three cases, all of aortic insufficiency with angina, could he be sure of improvement. Others, too, have used salvarsan in isolated instances, but give little information as to its value (Fiessinger, Goldscheider, Biermann, Hirtz and Braun, Schminke ${ }^{73}$ ).

Salvarsan has been given to 20 of my series of cases. Among these there were 14 of aortic insufficiency, 9 of which were associated with angina pectoris, or attacks of paroxysmal dyspnea, one of these latter having an aneurysm as well, 5 cases of aortitis associated with true angina, anginal pain or cardiac enlargement, and 1 case of aneurysm.

The drug has been given for the most part intravenously, but in 6 cases it was used before the intravenous method of administration became general, and was then given by the Lesser method intramuscularly. Three of these patients received intramuscular injections of $0.6 \mathrm{gram}, 2$ received $0.45 \mathrm{gram}$, and $1,0.5 \mathrm{gram}$. The remaining 14 cases have usually been given several doses of 0.3 gram intravenously. In this manner of divided dosage 4 cases have received 0.3 gram each, 2 cases 0.6 gram each, 4 cases 0.9 gram each, 1 case 1.2 gram, 1 case 1.8 gram and 1 case 3.0 grams. The doses have been given usually at intervals of eight to ten days. Salvarsan reactions have not been very common. Severe reactions with chills, fever and vomiting or diarrhea have occurred only six times in the thirty-seven administrations. During the last year freshly distilled water has always been employed.

In choosing the dosage I preferred to administer small amounts repeatedly, rather than one or two full doses; and after my rather limited experience this attitude seems justifiable, for it is possible that there is some danger in giving large doses, particularly in patients with angina pectoris and paroxysmal dyspnea.

73. Schminke: Reichs. Med. Anz., Leipz, 1911, xxxvi, 513, 545. 
Although death has occurred in eight of the twenty cases, in only one instance could it be even remotely connected with the injection. This one patient suffering from aortic insufficiency, and severe attacks of paroxysmal dyspnea and anginal pain, died suddenly within forty-eight hours of the first intravenous injection of 0.3 gram. Even this may have been a coincidence, for on another occasion a patient with angina died suddenly on the day before the first injection was to be made. Cardiac decompensation alone certainly does not seem to be a contra-indication. Seven patients were in a critical condition from decompensation when the first dose was given. Except in the case just described, if any effect was produced it was improvement.

All of the fatal cases suffered from aortic insufficiency. Four patients died of cardiac failure, one three weeks, three six months after treatment; one patient died of angina pectoris seven months after treatment; while one patient committed suicide one month after treatment.

In only one case (No. 6) was it possible to obtain an autopsy. The patient was in a hopeless state of cardiac decompensation when 0.45 gram of salvarsan was injected intramuscularly. He died three weeks later. Autopsy showed the typical gross appearance of syphilitic aortitis. Microscopically the lesion in the aorta appeared perhaps somewhat less cellular than the average, but did not differ materially from the lesions which have been seen in a number of other cases.

\section{SUMMARY}

The twenty treated cases have been summarized in the accompanying table (Table 1). It may be said once and for all that I have observed no definite beneficial effect on the cardiac incompetency itself, nor has there been any change in the anatomical condition. Signs of aortic insufficiency have not been reduced, nor have aneurysms grown smaller. And, indeed, when one comes to draw conclusions relative to the effect of certain therapy in a group of cases, the symptoms of which are so manifold and so varying, I am aware that the most extreme precautions are necessary. In such a small group, too, coincidences may deceive one, and I hare therefore attempted to preserve as critical an attitude as possible.

It has, however, been impossible to escape from the fact that certain of these patients have been benefited by salvarsan treatment, and this after all is not especially surprising, for these individuals must be regarded as suffering not only from a mechanical defect in the circulatory apparatus, but as well from a localized chronic infection. Thus it is reasonable to suppose that if this infective process is ameliorated, or cured, the general condition of the patient will likewise improve. In most instances this has been the case. The majority of patients feel considerably better after one or two injections. The patients who have 
improved sufficiently to go back to work report that they feel stronger and better than they have for years. Few, however, have gained weight, though the appetite increases.

The most striking result, however, has been the effect of treatment on the pain and attacks of paroxysmal dyspnea. In all but four cases, there has been permanent, or marked temporary or immediate improvement in this condition. In five cases there has been up to the present time permanent relief of pain. Two of these patients (Nos. 4 and 5 ) had suffered for one year when first observed. At the present time, two years after treatment, they are well and working hard. One patient (No. 14), who had suffered constantly from angina pectoris for two or three years, is well and working seven months after treatment. The fourth patient (No. 13), with aortic insufficiency, aneurysm and occasional attacks of paroxysmal dyspnea, is well and working hard six months after treatment; and in the fifth case (No. 11), though there has been repeated decompensation, pain of anginal nature which lad existed for five years, has recurred but once over a period of ten months.

In six cases there has been most striking temporary improvement. 'Two cases (Nos. 7 and 9) that had suffered for about a year with paroxysmal dyspnea accompanied by excruciating anginal pain, obtained complete temporary relief. 'This lasted in one instance for two months during which time the patient was able to go about and do a little work. At the end of this time the attacks recurred, became progressively worse and the patient finally died. In the other case the improvement of much the same nature, lasted only about four weeks. In another case (No. 2) there was relief from pain for six months. At the end of this time the pain recurred, and since then the patient has had almost constant decompensation. In one most striking case of angina pectoris (15) lasting orer a period of one year, with sometimes six and eight attacks a day, there has been almost, or indeed entire relief for periods of three weeks to a month after the injections of salvarsan, during which time the patient could attend to his daily work. At the end of this time the attacks recurred, gradually beconing more frequent and more severe, until he finally returned to the hospital for treatment. Occasionally he only remained in the ward one or two days, and twice only one night, so that the effect of rest or diet can be excluded. A second patient with angina pectoris (No. 12) left the hospital much improved and remained well for four weeks. Later he was lost sight of. Finally, a woman who had attacks of angina for nine months almost daily, and on any slight exertion, improved immediately while in the hospital, but later had a recurrence. During four days before salvarsan was given there were seven attacks. During the next two weeks after two doses of 0.3 gram of salvarsan, there were but two attacks. 
In the remaining cases there was one patient with aortic insufficiency with severe broken compensation (6), who was apparently unaffected; one of severe angina pectoris and aortic insufficiency (No. 8), who, after one intramuscular injection, showed no definite improvement, and died during an attack. One patient (No. 16), already described, who died forty-eight hours after the first injection; while the pain in one case of aneurysm with cervicobrachial neuralgia was uninfluenced after four intravenous injections of 0.3 gram. The remaining five cases improved considerably during their stay in the hospital, but have either been under observation too short a time to say what the result will be, or have been lost sight of.

In the study of these cases one fact has been very strongly impressed on me, and that is the persistence of a positive Wassermann reaction, or the rapid return of a positive reaction after a temporary abatement during treatment. There were eleven cases in which the Wassermann test could be repeatedly performed. In four of these only has it been possible to obtain, so far, a persistently negative reaction. All four cases showed marked improvement in symptoms (Nos. 2, 5, 11 and 13). In the cases (Nos. 9 and 15) it has diminished in intensity coincident with a relief in symptoms only to return again and become strongly positive with the recrudescence in one instance of attacks of paroxysmal dyspnea, and in the other of angina pectoris. In the latter case the reaction was still positive, even though 3 grams have been given. In five other cases it has remained positive after the injection of 0.9 gram intravenously, and in one case after the injection of 0.6 gram intravenously. But the first relief of symptoms, even though temporary, has come soon after the first or second injection in most instances, and while the Wassermann reaction was still positive.

Thus the improvement in symptoms manifests itself very rapidly, and usually within four to six days after the injection. We have, however, noticed an interesting phenomenon in a number of instances, namely, an increase in severity of symptoms within twenty-four to fortyeight hours after intravenous injections. This has been most striking in cases of angina pectoris and paroxysmal dyspnea. During the day or two following injections the paroxysms of dyspnea or attacks of angina increase in severity and number, then rapidly diminish and entirely disappear. This was most striking in one case of angina pectoris that received on three occasions 0.6 gram intravenously. A careful record was kept of the number of attacks during these periods and the accompanying chart (Fig. 6) illustrates the characteristic effect.

I cannot but feel convinced that treatment by salvarsan does have a distinctly beneficial effect on the pain and paroxysmal dyspnea in syphilitic aortitis, but as I have had more and more opportunity to study these cases, it has become increasingly evident that a cure is exceedingly 
difficult to accomplish. But the very rapid amelioration of the pains, attacks of angina pectoris and paroxysmal dyspnea is not only important for the patient, but perhaps suggests ccrtain explanations for these symptoms. So closely are the attacks of paroxysmal dyspnea associated with angina pectoris in this group of cases that here at least I prefer to consider them together.

I am aware that many explanations have been offered to account for the phenomena, and the theories of angina pectoris are legion. The frequent occurrence of lesions about the sigmoid region, and in the immediate vicinity of the coronary arteries, has led most observers to

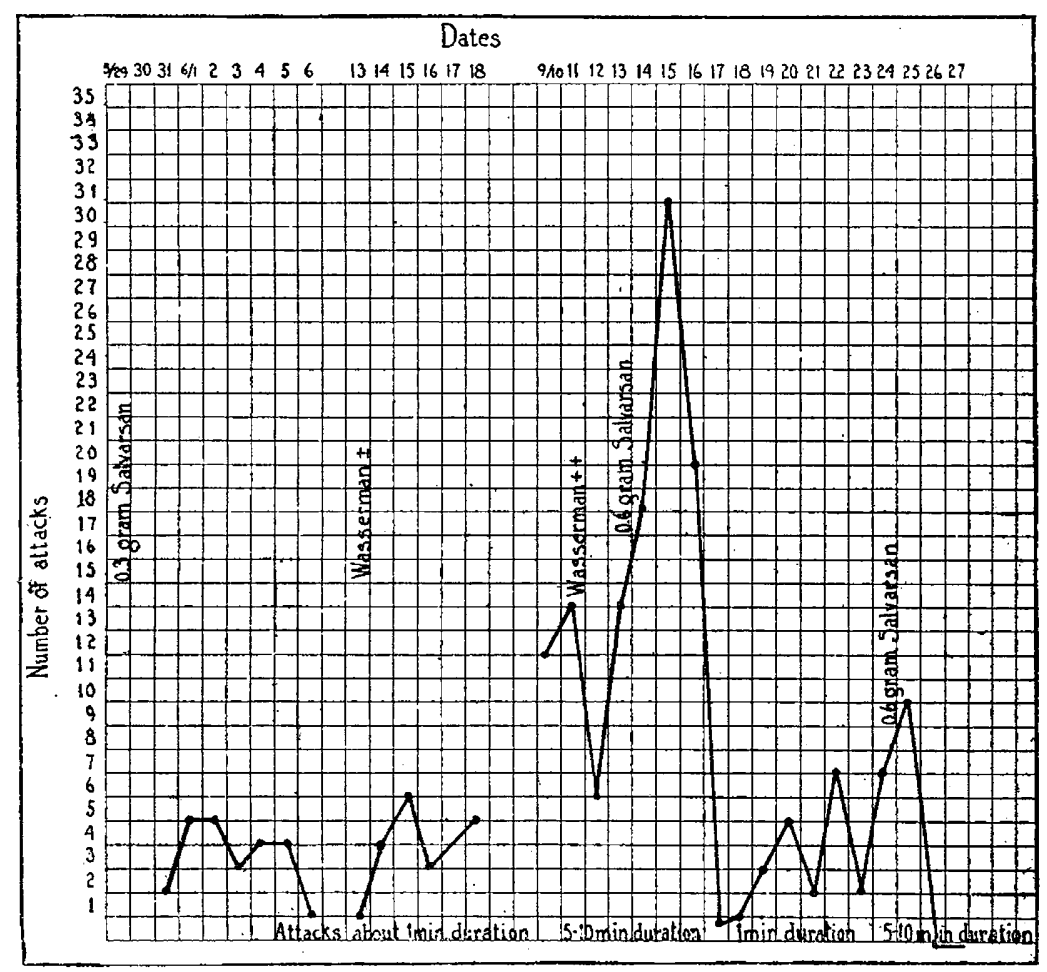

Fig. 6.-Chart with curve showing the number and duration of attacks of angina following the intravenous administration of salvarsan in a case of angina pectoris.

infer that disturbances in coronary circulation in this class of cases was responsible for the attacks of angina pectoris, and, perhaps, the attacks of paroxysmal dyspnea as well. The conditions, however, are complicated. One has to deal with an active infection at the root of the aorta to which the nerve supply is rich, and where in consequence disturbing reflexes may be excited; frequently involvement of the coronary circulation, and in a large proportion of instances, actual insufficiency of the aortic valves with the resultant changes in pressure in the left ventricle and their effects. It is impossible here to discuss the subject of angina 
pectoris. I need only refer to the works of Huchard, Rosenbach, ${ }^{74}$ Osler, ${ }^{75}$ Von Neusser ${ }^{i 6}$ and Mackenzie. ${ }^{7 \pi}$

We have not in the least been able to convince ourselves from autopsies in these cases that there was any direct association between disease of the coronary arteries and attacks of angina pectoris or paroxysmal dyspnea. Almost complete occlusion of the mouths of the coronary arteries has been found without either symptom appearing during life, and attacks of angina and paroxysmal dyspnea have occurred in cases which at autopsy showed large coronary arteries with wide mouths.

That these attacks may be associated with acute distention of the ventricle is possible, since all have occurred in cases of aortic insufficiency, but certainly such attacks are much more common in syphilitic aortitis than in aortic insufficiency caused by rheumatic fever.

The study of my cases, however, has suggested very strongly that these symptoms are closely associated with the inflammatory reaction at the root of the aorta, and are directly dependent on it. 'The fact first that symptoms may increase temporarily in severity following intrarenous injections of salvarsan, and that the most pronounced reactions have occurred with the largest doses lends support to the idea that this represents, as it were, a Herxheimer reaction, and that the increase in symptoms is due to the increased reaction of the tissues towards the liberation of toxin in excess from rapidly destroyed spirochetes. Following this there is rapid subsidence of symptoms, so rapid, indeed, that it could scarcely be ascribed to very great modification in anatomical structure. 'There might, however, be rapid improvement in the inflammatory reaction. Finally, the temporary relief of symptoms with severe recrudescences could best be explained by associating the symptoms directly with the progress of the inflammation.

The paroxysmal dyspnea, as I have already suggested, simulates rery closely an attack of asthma, and on account of the sudden onset, the violent type of expiratory dyspnea with suffocating sensations, the acute emphysema, and rapid subsidence, it impresses one as an acute temporary bronchospasm. That such an explanation holds for many cases of true asthma, seems most probable. Indirectly, too, the recent experiments of Januske and Pollak ${ }^{78}$ have some bearing on the question, for they have been able to offer an explanation for the beneficial effect of epinephrin in asthma. They found that the marked bronchiospasm caused by the injections of muscarin or peptone in animals was promptly relieved by injections of epinephrin and less rapidly, but more permanently by atropin. Pal, ${ }^{79}$ too, has reported that such substances as epi-

74. Rosenbach: Die Krankheiten des Herzens, 1897.

75. Osler: Angina Pectoris, 1897.

76. Von Neusser: Angina Pectoris, 1909.

77. Mackenzie: Lancet, London, 1895, i, 16.

78. Januske and Pollak: Arch. f. exper. Pathol. u. Pharmakol., 1911, 1xvi, 205.

79. Pal: Deutsch. med. Wchnschr., 1912, xxxviii, 5. 
nephrin, atropin, caffein and the nitrites which act as vasodilators to the coronary arteries, produce a dilatory effect as well on the bronchial musculature. Recently Park, ${ }^{80}$ by direct experiment, has confirmed these results obtained with epinephrin. In the cases of paroxysmal dyspnea nitroglycerin, as mentioned before, seems to have some effect in cutting short the attack, and in cases which have been watched for days or even weeks in the wards before salvarsan was given it was the only drug which seemed to have any influence. It is possible that, if it had any effect at all, it is through a relief of bronchiospasm, and not from its action on the coronary arteries. Atropin has been employed a few times, but not sufficiently often to say anything regarding its action. Epinephrin I have feared to use.

Having still more important bearing on this subject are some old experiments of François Frank ${ }^{s 1}$ on aortic reflexes. By irritating the inner surface of the aorta of dogs he was able to produce quite constantly certain respiratory phenomena. These consisted of three types: (1) Sudden apnea with the respiratory muscles in spasm either during the inspiratory or expiratory phase, or apnea with general inhibition of all respiratory movements; (2) tachypnea, without severe constitutional symptoms, and (3) a slow dyspnea of severe and grave form. The cause of this dyspnea he showed quite plainly was spasm of the bronchial musculature. He believed, too, that there was coincident contraction of the pulmonary artery. Associated with this type of dyspnea was a contraction of the peripheral vessels and rise of blood-pressure. Occasionally a spasm of the laryngeal muscles occurred. In other cases he was able to produce all the signs of aortic insufficiency (the capillary and collapsing pulse) save a diastolic mumur through irritation of the root of the aorta and without injury to the sigmoid valves. Stewart ${ }^{82}$ has observed this last phenomenon and considers it as a reflex from the root of the aorta, and in some experiments in which aortic insufficiency was performed on dogs I have repeatedly confirmed this observation. That Frank's respiratory phenomena have not been noted since is almost certainly due to the method of experimentation, for in Stewart's experiment, and in those which others have performed, full ether anesthesia or artificial respiration was employed.

It is thus evident that disturbing reflexes may be set up experimentally in animals by irritation of the root of the aorta, and there is no reason to suppose that the same thing should not be true for man. The dyspnea caused by bronchiospasm, and the contraction of the peripheral arteries producing heightened blood-pressure in the experimental animal

80. Park: Jour. exper. Med., 1912, xvi, 568.

81. Frank, François: Arch. de Physiol., 1890, stries 5, ii, 508 and 547; Jour. le l'anat., 1977, xiii, 545.

82. Stewart: Tine Afchives Ixt. Mr., 1908, i, 102. 
is a close reproduction of the paroxysmal dyspnea as it occurs in syphilitic aortitis, and it seems quite justifiable to suggest that the two conditions are the same. It would be difficult to explain the increase in bloodpressure which occurs during these attacks in man on the presence of pain, or of cyanosis, for pain is frequently absent and dyspnea may continue for some time (fifteen to thirty minutes) after the sudden drop in blood-pressure which comes with the relief of acute symptoms. Our observations, therefore, seem to lend strong support to the idea that these symptoms are dependent on a reflex generated at the root of the aorta by the syphilitic infianmatory process.

Hoover ${ }^{83}$ has recently called attention to certain respiratory phenomena which he believes are associated with disturbances of the vagus nerre. In two cases there were attacks of paroxysmal dyspnea and acute emphysema associated in one with an inflammatory mass in the mediastinum, and in another with aneurysm of the arch of the aorta. In both these cases the vagi were found at autopsy involved in the tumor masses. In two other cases of aortic insufficiency there occurred attacks of tachypnea associated with slow pulse. Both patients were relieved by atropin.

Though there is no positive evidence other than the results of treatment that the cases of angina pectoris as well as those of paroxysmal dyspnea in this group are of reflex origin, the definite Herxheimer reaction combined with the rapid improvement and later recurrences suggest that the actual inflammation of the wall of the aorta is of great importance in determining the onset of these attacks. The immediate cause of the attacks of angina may of course be constriction of the coronary arteries, but the true etiology probably lies in the diseased aorta, and not in the coronary arteries themselves.

There are not lacking those who have regarded angina pectoris as a reflex depending on reflex nerve impulses. Nothnagel's ${ }^{84}$ theory of angina pectoris vasomotoria is well-known. Huchard, though recognizing that inflammations about the root of the aorta might cause a reflex angina pectoris from involvement of the nerves, would exclude such cases from the category of true angina pectoris. Recently this whole question has been discussed by Heitz. ${ }^{65}$ Actual disease of the cardiac plexuses has been described by Benenatiss in two of three cases of syphilitic aortitis with angina pectoris, but others have not been able to confirm these findings. It does not seem necessary, however, to presuppose such lesions, since involvement of the nerve endings in the root of the aorta might be sufficient to determine the onset of reflexes.

The question, of course, complicated as it is, should be put to experimental proof before going further, but the suggestion that these attacks

83. Hoover: Jour. Am. Med. Assn., 1911, Ivii, 1733.

84. Nothnagel: Deutsch. Arch. f. klin. Med., 1867, iii, 309.

85. Benenati: Riforma med., 1902, ii, 326. 
of paroxysmal dyspnea and angina pectoris in this particular class of case are directly connected with the syphilitic inflammation at the root of the aorta, and that these symptoms are of reflex nature rather than dependent on anatomical lesions of the coronary arteries, seems in accord with my observations.

The permanent relief of these symptoms can only be obtained, if at all, by the most persisient treatment. It is probably difficult to reach the spirochetes by the blood-stream, so that the diseased aorta is hard to attack. I have been more and more impressed with the necessity of giving repeated doses of salvarsan, and am now not as much discouraged by recurrences as at first. It may be that neosalvarsan will prove more efficacious, or the combination of salvarsan with injections of mercury. Salvarsan, however, would seem to be the best method of primary attack, since the symptoms which may be relieved are immediately dangerous to the life of the patient. The possibility of producing a Herxheimer reaction in cases with paroxysmal dyspnea and angina pectoris should be constantly borne in mind, and in such instances full doses might bring about an alarming immediate increase in symptoms or sudden death.

\section{CONCLUSIONS}

Syphilis produces a characteristic lesion of the aorta, which is responsible, as is shown by autopsy statistics and the Wassermann reaction, for most aneurysms, about 75 per cent. of cases of aortic insufficiency in adults, many cases of dilatation of the aorta, and a certain group of cases of angina pectoris.

The infection of the aorta probably takes place during the secondary stage, and though the symptoms and signs of syphilitic aortitis with the complications may develop within a few months of infection, the process usually remains latent, or unrecognized for an average of sixteen to seventeen years. Thus, syphilitic aortitis is probably a common cause for the presence of a positive Wassermann reaction in so-called latent syphilis.

The early symptoms and signs of syphilitic aortitis are a positive Wassermann reaction, precordial pain, slight dyspnea, attacks of paroxysmal dyspnea and angina pectoris, cardiac hypertrophy, increased pulsation of the vessels of the neck and signs of dilatation of the aorta.

The precordial pain, paroxysmal dyspnea and angina pectoris are temporarily or permanently relieved by repeated injections of salvarsan, but in certain instances these symptoms, especially after large doses, may be aggravated for the first forty-eight hours after injection.

The paroxysmal dyspnea, which may be regarded as acute bronchiospasm, and possibly the angina pectoris in syphilitic aortitis is dependent on the inflammatory reaction in the wall of the aorta, and may be regarded as reflex disturbances set up by the syphilitic process involving the root of the aorta.

680 Madison Avenue. 